\title{
Prognosis in complex regional pain syndrome 1
}

Citation for published version (APA):

Brunner, F. (2010). Prognosis in complex regional pain syndrome 1. [Doctoral Thesis, Maastricht University]. Maastricht University. https://doi.org/10.26481/dis.20100121fb

Document status and date:

Published: 01/01/2010

DOI:

$10.26481 /$ dis.20100121fb

Document Version:

Publisher's PDF, also known as Version of record

\section{Please check the document version of this publication:}

- A submitted manuscript is the version of the article upon submission and before peer-review. There can be important differences between the submitted version and the official published version of record.

People interested in the research are advised to contact the author for the final version of the publication, or visit the DOI to the publisher's website.

- The final author version and the galley proof are versions of the publication after peer review.

- The final published version features the final layout of the paper including the volume, issue and page numbers.

Link to publication

\footnotetext{
General rights rights.

- You may freely distribute the URL identifying the publication in the public portal. please follow below link for the End User Agreement:

www.umlib.nl/taverne-license

Take down policy

If you believe that this document breaches copyright please contact us at:

repository@maastrichtuniversity.nl

providing details and we will investigate your claim.
}

Copyright and moral rights for the publications made accessible in the public portal are retained by the authors and/or other copyright owners and it is a condition of accessing publications that users recognise and abide by the legal requirements associated with these

- Users may download and print one copy of any publication from the public portal for the purpose of private study or research.

- You may not further distribute the material or use it for any profit-making activity or commercial gain

If the publication is distributed under the terms of Article $25 \mathrm{fa}$ of the Dutch Copyright Act, indicated by the "Taverne" license above, 


\section{PROGNOSIS IN COMPLEX REGIONAL PAIN SYNDROME 1}

Florian Brunner

2010 
(c) Copyright F. Brunner, Zürich 2010

ISBN 9789052789101

Universitaire Pers Maastricht

Layout and print: Datawyse bv, Maastricht 


\title{
PROGNOSIS IN COMPLEX REGIONAL PAIN SYNDROME 1
}

\author{
PROEFSCHRIFT \\ ter verkrijging van de graad van doctor aan de Universiteit Maastricht, \\ op gezag van de Rector Magnificus, \\ Prof. mr. G.P.M.F. Mols \\ volgens het besluit van het College van Decanen, \\ in het openbaar te verdedigen \\ op donderdag 21 januari 2010 om 10.00 uur
}

door

\section{Florian Brunner}

geboren te Zürich, Zwitserland, op 4 augustus 1969

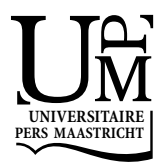




\section{Supervisor}

Prof. dr. M. van Kleef

\section{Co-supervisor}

PD dr. L.M. Bachmann (University of Zurich)

\section{Assessment Committee}

Prof. dr. R.J.E.M. Smeets (voorzitter)

Prof. dr. J. J. Van Hilten (Universiteit Leiden)

Prof. dr. M. A. E. Marcus

Dr. J. Van Zundert

Prof. dr. W.W.A. Zuurmond (Vrije Universiteit Amsterdam)

This study was performed within TREND (Trauma Related Neuronal Dyfunctions), a knowledge consortium that integrates research on CRPS type 1, and is supported by a Dutch government Grant (BSIK 03016). 


\section{Table of Contents}

Chapter 1 General Introduction 7

Chapter 2 Disease-related knowledge of patients with Complex Regional 11 Pain Syndrome

Chapter 3 Diagnostic criteria and follow-up parameters in Complex

Regional Pain Syndrome type 1- a Delphi survey

Chapter 4 Complex Regional Pain Syndrome 1 - the Swiss cohort study 33

Chapter 5 German translation and external validation of the Radboud 45

Skills Questionnaire in patients suffering from CRPS 1

Chapter 6 Translating the Dutch Walking Stairs, Walking Ability and Rising and Sitting Questionnaire into German and assess its construct validity with VAS measures of pain and activity in daily living

Chapter 7 Bisphosphonates for the therapy of Complex Regional Pain Syndrome 1 - systematic review

Chapter 8 General discussion 85

$\begin{array}{ll}\text { Summary } & 89\end{array}$

Samenvatting 93

$\begin{array}{ll}\text { Dankwoord } & 97\end{array}$

$\begin{array}{ll}\text { Curriculum vitae } & 99\end{array}$

List of publications (last update September 24th, 2009) 101 



\section{CHAPTER 1}

General Introduction 
CRPS is a painful condition with clinical features that include pain, sensory, sudomotor and vasomotor disturbances, trophic changes and impaired motor function [1]. Two types of CRPS can be distinguished: type 1, formerly known as reflex sympathetic dystrophy or algodystrophy, which occurs without a definable nerve lesion and type 2, formerly called causalgia, in which a definable nerve lesion is present [2]. Symptoms usually appear after an initiating noxious event such as trauma and surgery [3, 4]. The incidence from CRPS 1 varies from 26.2-5.46/100'000 [3, 4] affecting mainly women [3, 4] in the age between 46-70 years [3, 4]. The upper extremity is up to four times more affected than the lower extremity [3-5].

Symptoms usually appear after an initiating noxious event such as trauma or surgery. The course varies from mild and self-limiting to chronic disease with a high impact on daily functioning and quality of life. CRPS is often associated with a significant morbidity and loss of quality of life. In Turkey, almost a third of patients with CRPS are not returning to work. In a retrospective chart review of 143 patients with CRPS who had been assessed and treated at a university based pain centre in the United States, over half of all patients were involved in worker compensation claims and a fifth of all patients in law suits.

Because of the broad spectrum of clinical manifestations of CRPS, there is no characteristic and unique feature which helps to distinguish CRPS from other condition with similar manifestations. Hence, the diagnosis is solely based on clinical manifestations (signs and symptoms). Additional diagnostic tools such as blood samples, x-ray, magnetic resonance imaging and bone scan do not help to improve the validity of the diagnosis of CRPS. In order to standardise the diagnostic process, several attempts have been made to develop valid diagnostic criteria. Currently, the criteria introduced by the International Association for the Study of Pain (IASP) [6], Veldman [7] and Brühl [8] are most commonly used in clinical practice. So far, only the IASP criteria have been validated showing an acceptable sensitivity but low specifity [8-10] and a poor intraobserver reliability [11]. In a Delphi experiment an international panel of experts agreed on a reduced list of relevant diagnostic items [12]. To improve the specifity, another international consensus group proposed a revision oft the IASP criteria for CRPS 1 (Budapest criteria) [13]. Only recently, Harden et al. [14] published an updated, empirically validated and statistically derived revision of the IASP criteria which shows higher specificity. In contrast to the old version, the new proposed criteria (Budapest criteria) combine signs and symptoms and introduce two sets with different decision rules for use in clinics or research.

Despite increasing research in this field CRPS remains a challenging disorder. The exact mechanisms of the onset and course of the disease are still unknown. In particular, limited data is available on epidemiology, natural history and possible predisposing factors. Reasons are the lack of reliable diagnostic criteria as well as missing patients with a mild course of the disease. Due to a lack of controlled trials, therapeutic interventions remain controversial. According to the several guidelines, treatment should be initiated as soon as possible and should be based 
on a multimodal, interdisciplinary approach including pharmacological, functional restoration and psychological treatment [17-20]. However, despite intensive therapeutic interventions, some patients suffer from persistent pain and functional disability.

Information regarding relevant prognostic factors in CRPS is sparse or difficult to interpret, due to the specificity of circumstances in which the information was collected [21]. For the initiation of CRPS 1 certain psychological characteristics such as depression, recent life events or emotional instability are considered to be prognostic factors [22]. The nature and severity of the initiating event seem not to have a prognostic value on the course of the disease [7]. In the literature, the following parameters have been identified as prognostic factors for delayed recovery: duration of the complaints (more than 90 days), cold CRPS 1, passive coping style and poor controllability of the complaints [23, 24].

In clinical practice I see many patients presenting with persistent pain and activity limitations which turn out to have a case of a Complex Regional Pain Syndrome (CRPS). Despite that CRPS is quite common and that annual health expenditures amount to billions of Euros in Europe, our understanding regarding diagnosis and treatment of this condition are very limited. This observation stimulated my research activities over the last few years.

The research presented in this thesis comprises a series of projects aiming to address the following research questions:

- What do CRPS 1 patients actually know about their condition and where do they gather their information from? (Chapter 2)

- Do experts agree on a priority list of diagnostic and follow-up parameter in the diagnosis and management of CRPS 1 ? (Chapter 3)

- What is a possible design for a cohort study aiming at epidemiological, diagnostic, prognostic and socioeconomic investigations for patients with suspected early CRPS 1? (Chapter 4)

- Is the German translation of the Radboud Skills Questionnaire a tool to assess disability in CRPS 1 patients? (Chapter 5)

- Are the Walking Stairs, Walking Ability and Rising and Sitting Questionnaire tools to assess disability in CRPS 1 patients? (Chapter 6)

- What is the efficacy of bisphosphonates in the treatment of CRPS 1? (Chapter 7)

The studies were performed at the Balgrist University Hospital in Zurich, Switzerland in close collaboration with the Horten Centre for Patient Oriented Research, of the University of Zurich (Switzerland). 


\section{References}

1. Bruehl S, Harden RN, Galer BS, Saltz S, Backonja M, Stanton-Hicks M. Complex regional pain syndrome: are there distinct subtypes and sequential stages of the syndrome? Pain 2002; 95(12): 119-24.

2. Stanton-Hicks M, Janig W, Hassenbusch S, Haddox JD, Boas R, Wilson P. Reflex sympathetic dystrophy: changing concepts and taxonomy. Pain 1995; 63(1): 127-33.

3. de Mos M, de Bruijn AG, Huygen FJ, Dieleman JP, Stricker BH, Sturkenboom MC. The incidence of complex regional pain syndrome: a population-based study. Pain 2007; 129(1-2): 12-20.

4. Sandroni P, Benrud-Larson LM, McClelland RL, Low PA. Complex regional pain syndrome type I: incidence and prevalence in Olmsted county, a population-based study. Pain 2003; 103(1-2): 199-207.

5. Duman I, Dincer U, Taskaynatan MA, Cakar E, Tugcu I, Dincer K. Reflex sympathetic dystrophy: a retrospective epidemiological study of 168 patients. Clin Rheumatol 2007; 26(9): 1433-7.

6. Merskey $\mathrm{H}$, Bogduk $\mathrm{N}$, Classification of chronic pain: description of chronic pain syndrome and definitions of pain terms. 2nd. ed. 1994, Seatle: IASP Press.

7. Veldman PH, Reynen HM, Arntz IE, Goris RJ. Signs and symptoms of reflex sympathetic dystrophy: prospective study of 829 patients. Lancet 1993; 342(8878): 1012-6.

8. Bruehl S, Harden RN, Galer BS, Saltz S, Bertram M, Backonja M, et al. External validation of IASP diagnostic criteria for Complex Regional Pain Syndrome and proposed research diagnostic criteria. International Association for the Study of Pain. Pain 1999; 81(1-2): 147-54.

9. van de Vusse AC, Stomp-van den Berg SG, de Vet HC, Weber WE. Interobserver reliability of diagnosis in patients with complex regional pain syndrome. Eur J Pain 2003; 7(3): 259-65.

10. Brunner F, Lienhardt SB, Kissling RO, Bachmann LM, Weber U. Diagnostic criteria and follow-up parameters in complex regional pain syndrome type I - a Delphi survey. Eur J Pain 2008; 12(1): 48-52.

11. Harden R, Bruehl S. CRPS: Current Diagnosis and Therapy. In: Wilson P, Stanton-Hicks M, editors. Diagnostic criteria: The statistical derivation of the four criterion factors. Seattle, WA: IASP Press; 2005. p. 45-58.

12. Harden RN, Bruehl S, Stanton-Hicks M, Wilson PR. Proposed new diagnostic criteria for complex regional pain syndrome. Pain Med 2007; 8(4): 326-31.

13. Geertzen JHB, Perez RSGM, Dijkstra PU, Kemler MA, Rosenbrand CJGM, Complex regional pain syndrome 1 guidelines., Specialists NSoR, Anaesthesiologists NSo, Editors. 2006, Van Zuiden Communications B.V.: Alphen an den Rjin.

14. Harden N, ed. Complex regional pain syndrome: treatment guidelines. 2006, RSDSA Press: Milford, CT.

15. Stanton-Hicks M, Baron R, Boas R, Gordh T, Harden N, Hendler N, et al. Complex Regional Pain Syndromes: guidelines for therapy. Clin J Pain 1998; 14(2): 155-66.

16. Stanton-Hicks MD, Burton AW, Bruehl SP, Carr DB, Harden RN, Hassenbusch SJ, et al. An Updated Interdisciplinary Clinical Pathway for CRPS: Report of an Expert Panel. Pain Pract 2002; 2(1): 1-16.

17. Perez RS, Van Hilten JJ, Marinus J, TREND: Source document 1 - Study designs and outcomes (Version 5). 2007.

18. Geertzen JH, de Bruijn H, de Bruijn-Kofman AT, Arendzen JH. Reflex sympathetic dystrophy: early treatment and psychological aspects. Arch Phys Med Rehabil 1994; 75(4): 442-6.

19. Perez RS, Brum PE, Rijnsburger ER, Zuurmond WA, de Lange JJ. Predictive value of pain, temperature, volume and range of motion in complex regional pain syndrome typ 1. Anaesthesiology 2001(95): A803.

20. Perez RS, Zuurmond WW, Bezemer PD, Kuik DJ, van Loenen AC, de Lange JJ, et al. The treatment of complex regional pain syndrome type I with free radical scavengers: a randomized controlled study. Pain 2003; 102(3): 297-307. 


\section{CHAPTER 2}

\section{Disease-related knowledge of patients with Complex Regional Pain Syndrome}




\section{Abstract}

Objective: In this survey we: 1) defined the minimum knowledge that a lay person affected with CRPS should have about this condition 2) investigated whether CRPS patients posses minimum knowledge and 3 ) identified patient characteristics associated with the level of knowledge.

Methods: Questionnaire interview in a population of 101 CRPS patients in Switzerland (mean age 54 years, 76 percent female). We developed and piloted a questionnaire containing questions regarding disease related knowledge. The level of knowledge was set in a consensus process among clinical experts and a CRPS patient. The set of questions (a maximum of 11 correct answers) was based on expert consensus about the minimum knowledge a lay person affected with CRPS should have. From each patient we obtained patient characteristics on age, gender, highest educational level and medical background.

Results: Only 6 patients (6\%) had minimum medical knowledge. Mean score for all patients was 7.6 (SD 2.1). We found slightly higher scores among patients with higher education (apprenticeship, vocational school $+0.38(95 \% \mathrm{Cl} ;-0.59$ to $1.34: p=0.44)$, university entrance diploma $+1.12(-0.16$ to 2.49 : $p=0.08$, university diploma, advanced technical college $+2.36(1.11$ to $3.61: p<0.001)$ compared to mandatory school) and professional medical background $+1.13(0.06$ to 2.20: $p=0.04)$. Most patients received information from their caregivers and would like know more about therapeutic strategies or general aspects of the condition.

Conclusion: Our data indicate that many CRPS patients do not reach minimum knowledge about their disease as defined by clinical experts. Physicians should be aware that CRPS patients expect disease related information first and foremost from their caregivers. In particular, the patients concerned seek more information about therapy and general aspects of the illness. 


\section{Introduction}

Patients' active participation is the cornerstone of a successful management of chronic diseases [1, 2]. However, active participation requires a minimum of understanding for the condition the patient is suffering from. A lack of knowledge promotes worries and fears but also unrealistic expectations regarding the course of illness [3-6]. It has been shown that patient knowledge can improve health outcomes [7]. However, this knowledge must be relevant for the patient and has to enable the patients to assume an important part in disease control and treatment. Complex Regional Pain Syndrome (CRPS) is often a debilitating chronic condition with a high impact on daily functioning and quality of life [8, 9]. For many patients living with CRPS is challenging since they often have to cope with physical and psychosocial problems [10]. Moreover, the pathophysiology and course of their condition are still a matter of debate, and it is impossible to predict how patients will respond to treatments [11]. Experiences in other chronic illnesses showed that good communication between practitioners and patients regarding the patients' perspective of the condition as well as the patient education are essential for a successful management, improvement of daily function and quality of life [12].

In clinical practice, physicians often assume that patients posses a certain minimum knowledge about their condition [13]. However, to date it is unknown whether CRPS 1 patients meet this expectation. Therefore, in this survey we: 1 ) defined the minimum knowledge that a lay person affected with CRPS should have about this condition 2) investigated whether CRPS patients posses minimum knowledge and 3) identified patient characteristics associated with the level of knowledge.

\section{Methods}

This study was approved by the local Ethics Committee and informed consent was obtained from all participants.

\section{Patient views}

Participants were asked where they received information about CRPS from and from whom they expect disease related information primarily. In addition, we asked what they would like to know more about the condition and whether they think that better knowledge would be related with better coping.

\section{Defining Minimum Knowledge}

In order to be able to test the patients' knowledge about CRPS, a panel consisting of eight clinical experts (two rheumatologists, one physical medicine \& rehabilitation specialist, one neurologist, one orthopaedic surgeon, one psychologist, one anaesthesiologist and one physiotherapist), and one patient affected with CRPS 1 , 
was asked to define the minimum medical knowledge a lay person affected with patient CRPS should have. The panel was instructed to be careful to state just the most common facts that should be known by CRPS patients. We transformed their statements into open format questions and implemented them in the questionnaire. The panel reached consensus about the level of knowledge and also confirmed the adequacy of the format. The questionnaire was then piloted on 10 patients with CRPS. Based on the feedback we produced the final version of the questionnaire.

The final version of the questionnaire consisted of 11 questions. The scoring range was 0 to 11 points (each correct answer giving 1 point). For the complete set of questions and the correct answers refer to the Box.

Box: Final version of the questionnaire with correct answers

\begin{tabular}{|c|c|}
\hline Question & Correct answer \\
\hline Do you know any other names for CRPS? & E.g. algodystrophy, Sudecks' disease etc \\
\hline $\begin{array}{l}\text { What is more common in the general popula- } \\
\text { tion: elevated blood pressure or CRPS? }\end{array}$ & Elevated blood pressure \\
\hline What is the difference between CRPS 1 and $2 ?$ & CRPS 2 with identifiable nerve injury \\
\hline What are the three stages of CRPS? & Acute (warm), dystrophic (cold) and atrophic stage \\
\hline $\begin{array}{l}\text { Do you know any initiating events of CRPS, other } \\
\text { than your own? }\end{array}$ & Trauma, surgery, immobilisation, idiopathic \\
\hline How is CRPS diagnosed? & Clinical diagnosis \\
\hline $\begin{array}{l}\text { Do you know any signs and symptoms of CRPS, } \\
\text { other than your own? }\end{array}$ & Sensory, autonomic, motor, trophic changes \\
\hline $\begin{array}{l}\text { Do you know any medications used in the treat- } \\
\text { ment of CRPS? }\end{array}$ & $\begin{array}{l}\text { Acetaminophen, nonsteroidal anti-inflammatory, } \\
\text { opioids, anticonsvulsiva, vitamin c, steroids, } \\
\text { calcitonin, antidepressants, DSMO, capsaicin }\end{array}$ \\
\hline $\begin{array}{l}\text { What treatments, other than medication, are } \\
\text { used in the treatment of CRPS? }\end{array}$ & $\begin{array}{l}\text { Physiotherapy, occupational therapy, psychological } \\
\text { and psychiatric interventions }\end{array}$ \\
\hline What is the main goal in the treatment of CRPS? & Functional restoration, pain reduction \\
\hline Is CRPS a psychological disorder? & No \\
\hline
\end{tabular}

\section{Recruitment sources}

We recruited patients through the outpatient clinic of Balgrist University Hospital in Zurich, Switzerland, through an ad on a self-help homepage for patients afflicted with CRPS 1 (www.morbus-sudeck.ch), and by contacting two regional self-help organisations. Forty-five patients attending the outpatient clinic where approached and 36 agreed to participate. 15 patients reacted on the web ad and all of them completed the survey. 45 patients out of approximately 60 patients attending two regular meetings held by two patient self-help organisations agreed to participate. 
Another five patients contacted us directly after hearing about this study. We included all eligible and consenting adult patients, fulfilling the IASP criteria for CRPS with illness duration of more than 3 months. The fulfilment of the IASP criteria was confirmed by reviewing the participants chart or by clinical examination (participants from our outpatient clinic). In cases where this was impossible, we obtained the information in a telephone interview with the patient.

\section{Data acquisition}

Eligible patients were contacted and invited to the interview if they agreed to participate in the survey. In order to minimize the possibility of a specific preparation prior to the interview, no details about the content of the questionnaire were given to the patients. Participants were assured that their individual comments are kept anonymously and were encouraged to express their own individual attitudes and expectations.

\section{Interviewer}

One interviewer received an oral and written instruction on how to conduct the interviews and was trained on five subjects. The interviewer was not involved in the patients' treatment or the development of the questionnaire.

\section{Statistical analysis}

First, the cumulative number of correct replies was counted across all questions. Assessment of correct replies was performed in duplicate according to the predefined replies, and discordances between the assessors were discussed. In cases of continued disagreement, particularly if the participant used an unusual term, we classified the answer as correct. Secondly, we assessed the association of level of knowledge on participants' highest education and possible professional medical background using two regression models, where the cumulative number of correct replies was the dependent and highest education or possible professional medical background were the independent variables. Independent variables were transformed into dummy variables (indicator variables). The lowest level acted as the baseline category. Statistical analysis was performed using the Stata 10 software package. (StataCorp, 4905 Lakeway Drive, College Station, TX, USA).

\section{Results}

\section{Study population}

The study population consisted of 101 patients. We enrolled 77 female (77\%), mean age (SD) was 54 years $( \pm 12), 97$ (96\%) were suffering from CRPS 1 with mean illness duration (SD) of 57.2 month $( \pm 48.5)$. The most common initiating 
event was surgery $(n=57 ; 56 \%)$ followed by trauma $(n=39 ; 39 \%)$. Details regarding affected body parts, education and medical background are shown in table 1.

Table 1: Characteristics of study population $(\mathrm{N}=101)$

\begin{tabular}{lc}
\hline & Number (\%) \\
\hline Number of participants & $101(100 \%)$ \\
Gender & \\
$\quad$ Male & $24(24)$ \\
$\quad$ Female & $77(77)$ \\
Mean (SD) age (years) & $54 \pm 12$ \\
Age range (years) & $17-80$ \\
CRPS 1 & $97(96)$ \\
CRPS 2 & $4(4)$ \\
Affected body part & \\
$\quad$ Hand & $35(34)$ \\
$\quad$ Foot & $40(40)$ \\
$\quad$ Knee & $8(8)$ \\
$\quad$ Shoulder-hand syndrome & $12(12)$ \\
$\quad$ l limb & $6(6)$ \\
Months with CRPS & $57.2 \pm 48.5$ \\
Initiating event & \\
$\quad$ Trauma & $39(39)$ \\
$\quad$ Surgery & $57(56)$ \\
$\quad$ Others & $5(5)$ \\
Education & $37(37)$ \\
$\quad$ Mandatory school & $32(32)$ \\
Apprenticeship, vocational school & $11(11)$ \\
University entrance diploma & $14(14)$ \\
University, advanced technical college & $6(6)$ \\
Others & \\
Medical background, self reported & $20(20)$ \\
Yes & $81(80)$ \\
No $\quad$ & $1(5)$ \\
Medical background, specified & $6(30)$ \\
$\quad$ Lab technician & $3(15)$ \\
$\quad$ Purse & $1(5)$ \\
$\quad$ Others (e.g. paramedical staff) & $9(45)$ \\
$\quad$ \\
$\quad$
\end{tabular}

\section{Patients' views}

Most patients received information from their physicians and expect disease related information primarily from their caregivers. In addition, patients concerned would like to know more about therapeutic strategies or general aspects of the condition. Most of the participants (84.2\%) think that better knowledge is related with better coping. For details, please refer to table 2 . 
Table 2: Questions regarding patient's views $(N=101)$

\begin{tabular}{llrr}
\hline Question & Answer & N & $\%$ \\
\hline Where did you obtain information & & 57 & 56 \\
about CRPS? & Physician & 54 & 54 \\
& Internet & 30 \\
& Self help organization & 30 & 11 \\
& Paramedical staff & 11 & 14 \\
& Print media & 14 & 6 \\
& Friends & 6 & 2 \\
\hline Through what source would you like to receive & Physician & 2 & 1 \\
\hline more information about CRPS? & Print media & 1 & 57 \\
& Patients concerned & 58 & 15 \\
& Self help organization & 15 & 3 \\
& Various & 1 & 1 \\
\hline On what topics would you like to get more & Therapy & 28 & 28 \\
\hline information? & General aspects & 39 & 39 \\
& Prognosis & 35 & 35 \\
\hline with better coping? & Pathophysiology & 25 & 25 \\
\hline & Results from research & 2 & 10 \\
\hline & Psychological aspects & 3 & 2 \\
\hline
\end{tabular}

\section{Minimum CRPS related knowledge}

Six patients $(6 \%)$ had minimum medical knowledge. Only ten patients knew the difference between CRPS 1 and CRPS 2. Most patients $(n=98)$ gave the correct answer to the question: "What is more common in the general population: elevated blood pressure or CRPS?" The detailed results from the interview are presented in figure 1.

We found slightly higher scores among patients with higher education (apprenticeship, vocational school $+0.38(95 \% \mathrm{Cl}$; -0.59 to $1.34: p=0.44)$, university entrance diploma $+1.12(-0.16$ to $2.49: p=0.08$, university diploma, advanced technical college +2.36 (1.11 to $3.61: p<0.001$ ) compared to mandatory school) and professional medical background $+1.13(0.06$ to $2.20: p=0.04)$. 


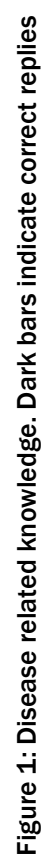

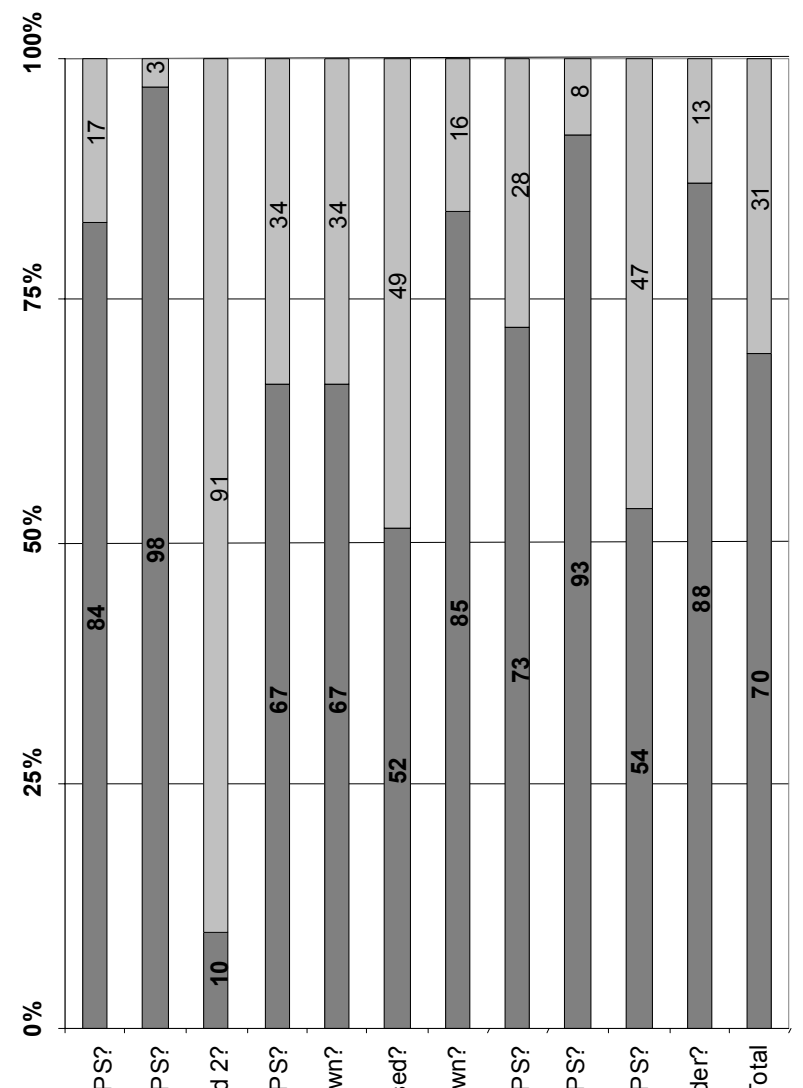

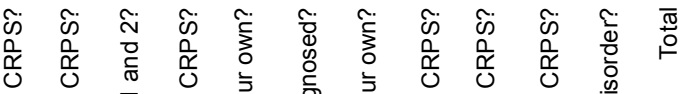

¿ั0

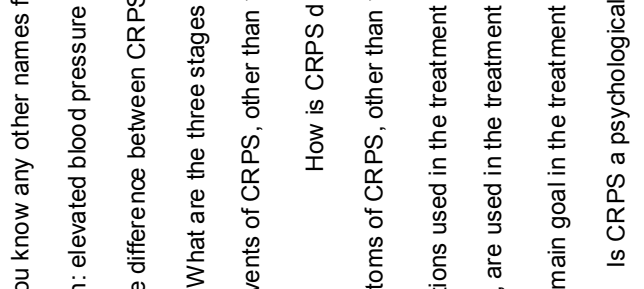

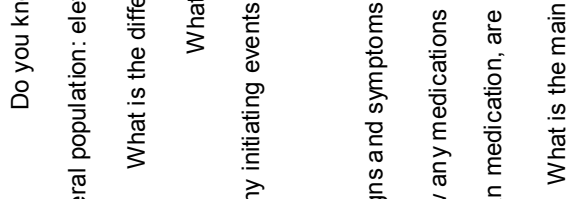

$\frac{\sqrt{0}}{\sqrt[0]{\pi}}$

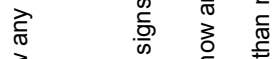

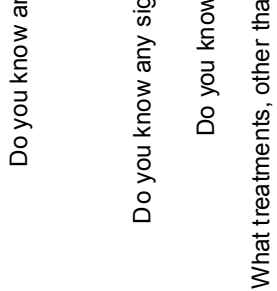




\section{Discussion}

The results of this survey are twofold: First only a small minority of the participants had a minimum CRPS knowledge as defined by clinical experts. Knowledge was slightly higher among patients with higher education or with medical background. Results remained mostly unchanged when correcting for potential confounders such as duration of symptoms, patients' age and gender. The low number of patients with minimum knowledge highlights the need for specific educational programs for our surveyed sample of patients. Second, most patients concerned receive disease related knowledge from their caregivers and would like to know more about therapy and general aspects of the condition.

After careful review of the English literature, no survey assessing patient knowledge of CRPS was found. This study is the first attempt to determine the level of disease related knowledge in CRPS patients and to identify information sources. The strength of this study includes the definition of the minimum medical knowledge by various experts in the field of CRPS and the relatively large number of participants. In order to minimize enrolment bias, we considered the level of education in our analysis, in particular possible medical background.

This study has several limitations. First, our recruitment process might be associated with a certain selection bias. We did not have data available from patients who were given the survey but did not return it; this could have possibly introduced bias. Since our call for participation was disseminated also via the internet it is likely that our sample contained patients with higher ease towards the World Wide Web. Arguably, patients with internet access may be more motivated to learn about the disease so that our sample might not be representative for a typical CRPS patient. Another limitation of this paper is that we had to develop a new assessment instrument rather than using an already established questionnaire. To our knowledge no such instrument is currently available. Arguably, other expert panels might come up with different knowledge dimensions and questions, which in return then would limit the generalisability of our findings. Moreover we compiled a group of experts of various clinical specialities and also a CRPS patient. In participants who were not patients from our clinic, we confirmed the diagnosis by applying the IASP criteria on the telephone.

Further research should aim at replicating our findings. Moreover we think that future research should be directed towards improving patient education. We propose the development of a specific protocol and patient briefing to improve patient education. However, evaluation of patient information or self-management programmes should consider that knowledge is only one component of a complex intervention. Self-management programmes for type 1 diabetes [14] or severe asthma [15] are examples of where patient knowledge as part of a complex intervention showed promising results towards a substantially improved treatment outcome. Only an educational intervention trial will indicate to what extent educational 
measures provided to patients with CRPS can have a sustained effect on treatment outcome or even quality of life. However, in 2001 Norris and colleagues published a systematic review assessing the effectiveness of self-management training in type 2 diabetes [16]. In a thorough examination they found that didactic interventions focusing only on the acquisition of knowledge and information, despite having some positive effects on knowledge showed only mixed results on clinically relevant outcomes such as glycemic control and blood pressure. They concluded that behavioural theory must have a more explicit role in future studies and highlighted the importance of programmes aiming at a behavioural change rather than isolated educational programmes focusing on improvement patients' knowledge.

In our view one important consequence emerges from our study. Physicians looking after patients with CRPS should address the topics covered within our minimum CRPS knowledge questionnaire. We believe that experience in other illnesses such as asthma and irritable bowel syndrome could serve as valuable role models when developing these programmes. The example of asthma has repeatedly shown that informed patients take more care of themselves have lower exacerbation rates and feel happier $[17,18]$. Even small improvements in treatment outcome or even quality of life as shown in this study can play an important role to patients particularly if treatment options have only limited effect on the course of debilitating symptoms.

This study's findings raise awareness that CRPS patients have a fairly high knowledge about their disorder. Physicians should be aware that CRPS patients expect disease related information first and foremost from their caregivers. In particular, the patients concerned seek more information about therapy and general aspects of the illness. 


\section{References}

1. Bodenheimer, T., et al., Patient self-management of chronic disease in primary care. Jama, 2002. 288(19): p. 2469-75.

2. Lorig, K. and H. Holman, Arthritis self-management studies: a twelve-year review. Health Educ Q, 1993. 20(1): p. 17-28.

3. Clark, R.A., et al., The impact of human immunodeficiency virus disease on academic health centers. Am J Med, 1998. 105(2): p. 87-90.

4. Eraker, S.A., J.P. Kirscht, and M.H. Becker, Understanding and improving patient compliance. Ann Intern Med, 1984. 100(2): p. 258-68.

5. Weiser, K.T., et al., Patient knowledge and perspective on irritable bowel syndrome: development of a survey instrument. Dig Dis Sci, 2008. 53(1): p. 284-95.

6. Jourdain, P., et al., Perception and understanding chronic heart failure by the patient. The impact of therapeutic education on the level of knowledge of patients. Arch Mal Coeur Vaiss, 2007. 100(3): p. 163-74.

7. Muhlhauser, I. and M. Lenz, Does patient knowledge improve treatment outcome?. Z Evid Fortbild Qual Gesundhwes, 2008. 102(4): p. 223-30.

8. Birklein, F., et al., Neurological findings in complex regional pain syndromes--analysis of 145 cases. Acta Neurol Scand, 2000. 101(4): p. 262-9.

9. Galer, B.S., et al., Course of symptoms and quality of life measurement in Complex Regional Pain Syndrome: a pilot survey. J Pain Symptom Manage, 2000. 20(4): p. 286-92.

10. Galer, B., L. Schwartz, and R. Allen, Complex regional pain syndromes - type I: reflex sympathetic dystrophy, and Type II: causalgia., in Bonica's management of pain, J. Loeser, Editor. 2000, Lippincott, Williams \& Wilkins: Philadelphia. p. 388-411.

11. Harden, R. and S. Bruehl, The statistical derivation of the four criterion factors, in CRPS: Current Diagnosis and Therapy, P. Wilson, M. Stanton-Hicks, and R. Harden, Editors. 2005, IASP Press: Seattle. p. 45-58.

12. Stewart, M.A., Effective physician-patient communication and health outcomes: a review. CMAJ, 1995. 152(9): p. 1423-33.

13. Williams, M.V., et al., Relationship of functional health literacy to patients' knowledge of their chronic disease. A study of patients with hypertension and diabetes. Arch Intern Med, 1998. 158(2): p. 166-72.

14. Forlani, G., et al., An empowerment-based educational program improves psychological well-being and health-related quality of life in Type 1 diabetes. J Endocrinol Invest, 2006. 29(5): p. 405-12.

15. Liu, C. and C. Feekery, Can asthma education improve clinical outcomes? An evaluation of a pediatric asthma education program. J Asthma, 2001. 38(3): p. 269-78.

16. Norris, S.L., M.M. Engelgau, and K.M. Narayan, Effectiveness of self-management training in type 2 diabetes: a systematic review of randomized controlled trials. Diabetes Care, 2001. 24(3): p. 561-87.

17. Thorsteinsdottir, B., et al., The ABCs of asthma control. Mayo Clin Proc, 2008. 83(7): p. 814-20.

18. Saito, Y.A., et al., Effects of multidisciplinary education on outcomes in patients with irritable bowel syndrome. Clin Gastroenterol Hepatol, 2004. 2(7): p. 576-84. 



\section{CHAPTER 3}

Diagnostic criteria and follow-up parameters in Complex Regional Pain Syndrome type 1 A Delphi survey 


\section{Abstract}

Objectives Although the current clinical guideline of diagnostic criteria for the Complex Regional Pain Syndrome 1 (CRPS 1) is a landmark endeavor to define this complex condition it does not prioritize its most important clinical manifestations. We set out to obtain an expert agreed priority list of diagnostic and follow-up parameters in the diagnosis and management of CRPS 1.

Methods A two round Delphi survey: We asked international experts to list (first round) and weight (second round) parameters (scale 1-10) they believed to be relevant in diagnosis and follow-up. Median ratings and interquartile ranges (IQR) were calculated. Rates $\geq 7$ and IQR $\leq 3$ depicted important and expert agreed parameters.

Results Thirty-two diagnostic and twenty-three follow-up listings and ratings of 13 experts were available for analysis. In three domains (clinical presentation, further examinations and follow-up) experts agreed on the following parameters, pain (10;9-10) with its subcategories hyperesthesia $(7 ; 5-8)$ hyperalgesia (8; 8-8) and allodynia (8;7-10), signs with edema (9;8-10) and color change $(8 ; 5-8)$ and mobility with its categories motor change $(7 ; 5-8)$ and decreased range of motion $(8 ; 8-8)$. The experts agreed that no further examinations were necessary for diagnosis (10;8-10). Agreed important follow-up parameters was clinical course $(10 ; 8-10)$ with its categories decrease in pain $(8 ; 8-9)$ and hyperalgesia $(8 ; 6-8)$, decreased edema (8;7-10) and improvements in motor function (10;8-10) and strength (8;6-9).

Conclusion This expert survey conveys an agreed set of relevant diagnostic parameters of CRPS 1 and proposes that in follow-up examinations treatment success should be based on restoration of those manifestations. 


\section{Introduction}

The Complex Regional Pain Syndrome type 1 (CRPS 1) describes a challenging neuropathic pain state [1;2]. From a clinical perspective, CRPS I commonly presents with regional pain and sensory changes following a noxious event [3]. Along with the pain, abnormal skin color, temperature change, abnormal sudomotor activity or edema may also be present [3].

Because of its broad clinical spectrum of manifestations, the International Association for the Study of Pain [IASP] introduced a new set of diagnostic criteria for CRPS 1 more than ten years ago [4]. However, according to a recent study a wide variety of diagnostic criteria are still applied in CRPS 1 research and only a minority of studies refer to the criteria as proposed by the IASP [5]. Many studies apply ad hoc clinical criteria, which makes the results of those studies difficult to compare [5].

We hypothesized, that the current diagnostic criteria are under used, because the IASP criteria are clinically difficult to adopt. Although the guideline meticulously defines the complex condition, it does not prioritize the most important clinical parameters. Therefore, in this study, we aimed at obtaining an expert agreed priority list of diagnostic and follow-up parameters in the diagnosis and management of CRPS 1 using a two-round Delphi survey among an international group of experts.

\section{Methods}

We conducted a two-round postal Delphi survey. At initiation, one researchers (RK) generated a list of potential members of the expert panel, a convenience sample of experienced clinicians in the field of CRPS 1 who where affiliated at University hospitals or tertiary centers. Each nominee received a letter including information about the aim of the study and an invitation to participate. We asked the participants to reply to the letter with their approval to participate within 2 weeks. In order to increase the response rate we sent a reminder to all experts.

All experts, who agreed to participate received a next letter requesting them to prepare two separate lists of parameters which in their personal opinion and experience are important clinical manifestations, further examinations and follow-up parameters of CRPS 1. All mentioned parameters were compiled into three separate lists, one for clinical characteristics, one for further examinations and another for follow-up parameters. Then these three lists were sent again to the experts asking them to weight each single parameter on both lists by assigning a number between one (not important) and ten (very important).

To identify the strongest diagnostic and follow-up parameters the median of the attributed weights and the corresponding inter-quartile ranges (IQR) were calculated. We arbitrarily defined the expert agreement if the IQR of a parameter was 
$\leq 3$. The optimal cut-off value of the median attributed weights for a relevant and agreed parameter was calculated drawing a ROC curve of the medians against an IQR classification of $\leq 3$ [6]. Based on this assessment we estimated the optimal cut-off value for a relevant item at a median attributed weight of $\geq 7$.

Statistical analyses were performed using the STATA 9.2 statistical software package (Stata, College Station, TX).

\section{Results}

The invitation letter was sent to twenty-eight experts, nineteen agreed to participate, and fourteen returned the first questionnaire. Thirteen experts from Switzerland $(n=3)$, United States of America $(n=4)$, Germany $(n=4)$, the Netherlands $(n=1)$ and Belgium $(n=1)$ completed the survey and provided thirty-two diagnostic and twenty-three follow-up listings for analysis. In three domains (clinical presentation, further examinations and follow-up parameters) experts agreed on the following parameters: pain $(10 ; 9-10)$ with its subcategories hyperesthesia $(7 ; 5-8)$ hyperalgesia $(8 ; 8-8)$ and allodynia $(8 ; 7-10)$, signs with edema $(9 ; 8-10)$ and color change $(8 ; 5-8)$ and mobility with its categories motor change $(7 ; 5-8)$, decreased range of motion $(8 ; 8-8)$ and strength $(7 ; 6-8)$. The experts agreed that no further examinations were necessary for diagnosis $(10 ; 8-10)$. The agreed important follow-up parameter was clinical course $(10 ; 8-10)$ with its categories decrease in pain $(8 ; 8-9)$ and hyperalgesia $(8 ; 6-8)$, decreased edema $(8 ; 7-10)$ and improvements in motor function $(10 ; 8-10)$, and strength $(8 ; 6-9)$.

The list of parameters with a median attributed weight of 7 or higher and an $\mathrm{IQR} \leq 3$ are shown in tables 1 (diagnostic criteria) and 2 (follow-up parameters). The remaining parameters are listed in the appendices. Temperature asymmetry for example fulfilled the importance criterion (median weight 8) but had a lower level of agreement (IQR 5-9). On the other hand experts agreed that criteria such as skin movability from the subcutis (median 3; IQR 2-4) or resolution of pain in advanced CRPS 1 stages (median 2; IQR 1-4) were less relevant for diagnosis (see Appendix 1 for details). In respect to follow-up parameters, absence of sympathetic maintained pain (SMP) reached a high median weight (7) but failed to reach consensus (IQR 2-7). Conversely, results of x-ray (median 1; IQR 1-2), parameters of bone remodeling $(2 ; 1-4)$ or three phase bone scintigraphy $(2 ; 1-3)$ were deemed less relevant for follow-up (see Appendix 2). 
Table 1 shows the set of diagnostic criteria of CRPS 1 fulfilling our selection criteria (median attribute weight of $\geq 7$ and an IQR $\leq 3$ )

\begin{tabular}{llcc}
\hline Parameter & Subcategory & Median & IQR (25-75) \\
\hline Pain & & 10 & $9-10$ \\
& Hyperesthesia & 7 & $5-8$ \\
& Hyperalgesia & 8 & $8-8$ \\
\multirow{3}{*}{ Signs } & Allodynia & 8 & $7-10$ \\
& Edema & 9 & $8-10$ \\
\multirow{3}{*}{ Mobility } & Color change & 8 & $5-8$ \\
& Motor change & 7 & $5-8$ \\
& Range of Motion (ROM) & 8 & $8-8$ \\
& Strength & 7 & $6-8$ \\
\hline
\end{tabular}

Table 2 shows the set of follow-up of CRPS 1 fulfilling our selection criteria (median attribute weight of $\geq 7$ and an IQR $\leq 3$ )

\begin{tabular}{llcc}
\hline Parameter & Subcategory & Median & IQR (25-75) \\
\hline Clinical course & & 10 & $8-10$ \\
& Decrease in pain & 8 & $8-9$ \\
& Hyperalgesia & 8 & $6-8$ \\
& Decreased edema & 8 & $7-10$ \\
& Improvements in motor function & 10 & $8-10$ \\
& Improvements in strength & 8 & $6-9$ \\
\hline
\end{tabular}

\section{Discussion}

In this Delphi survey, an international panel of experts agreed that diagnosis of CRPS 1 can be based on its clinical manifestations in the three domains pain, signs and mobility. Experts also agreed that no additional exams such as X-Ray or scintigraphy were required to confirm diagnosis. Finally, the results of this study also indicate that the course of illness can be monitored taking change of its clinical manifestations into account.

According to our knowledge this is the first Delphi survey exploring clinical and follow-up parameters in CRPS 1. The Delphi method has advantages compared to other consensus methods. It is capable to achieve agreement in a given area of uncertainty or lack of empirical evidence [7]. It is quick, cheap and allows combining the knowledge and abilities of an expert group anonymously [8]. Informal methods of reaching consensus, such as committees, are recognized to be prone to domination by powerful individuals, the biasing effects of personality traits, seniority and the fact that only one person can speak at a time [7]. In group consensus meetings, the presence and actions of others may inhibit creativity and the possibility of resolving ambiguous and conflicting issues [9]. 
Our findings are in accordance with those published in the official guidelines [2$4 ; 10]$. However, in addition to this, our study provides a priority list of CRPS 1 specific manifestations which allows weighing the importance of each criterion compared to another. We believe that the priority setting has its own practical clinical value. The set of important and agreed parameters could help clinicians to justify and standardize diagnosis of CRPS 1.

What are the limitations of this survey? It could be argued that our set of thirteen international experts in CRPS 1 of five countries was an inappropriate sample to represent experts worldwide and that thus our findings are poorly generalizable. Indeed, we cannot rule out, that another sample of experts might have come up with a different set of agreed parameters. However, the high concordance with parameters stated in the guidelines makes us confident that selection bias was not a major problem. Second, our questionnaire forced experts to weight each of the proposed parameters of the first round independently ignoring potential patters or manifestation clusters. We are aware that this somewhat artificial reply mode might have distorted some of the expert weightings. However, then again, this approach also enabled us to quantify the attributed weight of each parameter separately, which in response allowed straightforward direct comparisons between factors.

We think that the implications for research are twofold. First we would like to encourage researchers planning studies in this clinical field to adopt our set of diagnostic criteria for inclusion into studies. In the current literature researchers apply a broad spectrum of different diagnostic criteria, which inevitably leads to a poor comparability of research findings. Some critics even argue that it could be questioned whether different authors are really describing the same syndrome [11]. Second, in view, that underlying pathophysiological mechanisms of CRPS 1 remain largely unclear [12] we propose that further research should go into applied basic science [13]. From a practical point of view we suggest that clinical research should emphasize prognostic rather than diagnostic studies. Diagnostic research requires a firm illness definition and access to its defining elements [14], which at this stage is not available in CRPS 1. In terms of prognostic research, besides randomized drug evaluations, we believe that large cohorts of CRPS 1 patients evaluating current clinical care are essential to increase our understanding of mechanisms underlying health improvements in these patients.

A notable finding of this survey relates to the limited clinical value of upstream diagnostic testing in suspected CRPS 1 . This stays in sharp contrast to the plethora of new diagnostic tests that evolved in this context recently [13]. We argue that the poor agreement among our experts in relation to this depends on two mechanisms. First, in the rapidly growing field of diagnostic test evaluation, new promising candidates have not yet succeeded to convince clinicians of their additional value. Second, given that underlying mechanisms of CRPS 1 remain poorly understood, diagnostic studies are difficult to perform. It can be disputed that the lack of a reference or gold standard such as radiography or ct-scanning in bone 
fractures, impedes valid test evaluation research in CRPS 1. Therefore, physicians might prefer relying on a characteristic set of clinical manifestations and its change over time rather than on information coming from lab testing or imaging.

In conclusion, this Delphi survey among an international panel of clinical experts conveys an agreed set of relevant diagnostic parameters of CRPS 1 and proposes that in follow-up examinations treatment success should be based on restoration of those manifestations. 


\section{References}

1. Janig W, Baron R. Complex regional pain syndrome is a disease of the central nervous system. Clinical Autonomic Research. 2002;12:150-164.

2. Stanton-Hicks M, Baron R, Boas R, Gordh T, Harden N, Hendler $\mathrm{N}$ et al. Complex Regional Pain Syndromes: guidelines for therapy. Clin J Pain. 1998;14:155-66.

3. Stanton-Hicks M, Janig W, Hassenbusch S, Haddox JD, Boas R, Wilson P. Reflex sympathetic dystrophy: changing concepts and taxonomy. Pain. 1995;63:127-33.

4. Merskey $\mathrm{H}$, Bogduk N, eds. Classification of chronic pain: descriptions of chronic pain syndromes and definition of pain terms. Second Edition Seattle: IASP Press. 1994.

5. van de Beek WJ, Schwartzman RJ, van Nes SI, Delhaas EM, van Hilten JJ. Diagnostic criteria used in studies of reflex sympathetic dystrophy. Neurology. 2002;58:522-26.

6. Dincler S, Bachmann LM, Buchmann P, Steurer J. Predictors of Intra- and Postoperative Complications in Laparoscopic Colorectal Surgery: Results of an Expert Survey. Dig Surg. 2006;23:110114.

7. Murphy MK, Black NA, Lamping DL, McKee CM, Sanderson CF, Askham J et al. Consensus development methods, and their use in clinical guideline development. Health Technol Assess. 1998;2:i-88.

8. Lindeman CA. Delphi survey of priorities in clinical nursing research. Nurs Res. 1975;24:434-41.

9. Rowe G, Wright G, Bolger F. Delphi - A Reevaluation of Research and Theory. Technological Forecasting and Social Change. 1991;39:235-51.

10. Harden RN, Swan M, King A, Costa B, Barthel J. Treatment of complex regional pain syndrome: functional restoration. Clin J Pain. 2006;22:420-424.

11. Reinders MF, Geertzen JH, Dijkstra PU. Complex regional pain syndrome type I: use of the International Association for the Study of Pain diagnostic criteria defined in 1994. Clin J Pain. 2002;18:207-15.

12. Janig W, Baron R. Complex regional pain syndrome: mystery explained? Lancet Neurol. 2003;2:687-97.

13. Baron R, Janig W. Complex regional pain syndromes--how do we escape the diagnostic trap? Lancet. 2004;364:1739-41.

14. Bachmann LM, Juni P, Reichenbach S, Ziswiler HR, Kessels AG, Vogelin E. Consequences of different diagnostic "gold standards" in test accuracy research: Carpal Tunnel Syndrome as an example. Int J Epidemiol. 2005;34:953-55. 
Appendix 1 presents the diagnostic criteria of CRPS 1 which were proposed by experts in the first round but did not reach a consensus in the second round (median attribute weight parameters of $<7$ and an IQR $<3$ )

\begin{tabular}{lcc}
\hline Parameter & Median & IQR (25-75) \\
\hline Temperature asymmetry compared to unaffected side & 8 & $5-9$ \\
Pain of palpation & 6 & $6-8$ \\
Redness & 6 & $5-7$ \\
Perfusion & 6 & $4,5-8$ \\
Cyanotic skin & 6 & $4-8$ \\
Diffuse painfulness & 6 & $3-7$ \\
Sweating asymmetry compared to the unaffected side & 6 & $4-9$ \\
Missing lesion of nerve radices & 6 & $2-8$ \\
Hypertrichosis & 5 & $4-6$ \\
Trauma & 5 & $5-8$ \\
Trophic changes & 5 & $4-7$ \\
Differences in hair and nail growth & 5 & $4-7$ \\
Fibrosis of the affected joints, tendons and ligaments & 5 & $3-6$ \\
Stiffness of the joints & 5 & $4-8$ \\
Shiny cool skin & 5 & $3-7$ \\
Skin atrophy & 4 & $3-6$ \\
Motor changes & 4 & $3-7$ \\
Dystonia & 4 & $3-7$ \\
Increase in stiffness (stages II-III) & 4 & $3-8$ \\
Skin unmovable from the subcutis & $3-4$ \\
Not distinguishable from a somatoform disorder & 3 & $1-4$ \\
Tremor & 3 & $3-7$ \\
Resolution of pain (stage II-III) & 3 & $1-4$ \\
\hline & 2 & \\
\hline & & 2 \\
\hline
\end{tabular}


Appendix 2 presents the follow-up criteria of CRPS 1 which were proposed by experts in the first round but did not reach a consensus in the second round (median attribute weight parameters of $<7$ and an IQR $<3$ )

\begin{tabular}{lcc}
\hline Parameter & Median & IQR (25-75) \\
\hline Improvements in Range of Motion (ROM) & 8 & $6-10$ \\
Absence of SMP (sympathetic maintained pain if previously demon- & 7 & $2-7$ \\
strated) & 7 & \\
Psychometric measures (Pain disability index of SF-36) & 6 & $5-7$ \\
Quantity of analgesics required by the patient & 6 & $4-7$ \\
Decreased dystonia & 6 & $3-7$ \\
Decreased redness & 5 & $3-7$ \\
Normalization in temperature asymmetry & 5 & $2-6$ \\
Report by physical therapist & 5 & $1-7$ \\
Normalization of sweating & 4 & $2-6$ \\
Decreased tremor & 4 & $2-7$ \\
Return of sympathetic tone & 3 & $1-8$ \\
Course of QST (quantitative sensory testing) & 2 & $1-3$ \\
Regeneration of the movability between skin and subcutis & 2 & $1-3$ \\
Three phase bone scintigraphy & 2 & $1-4$ \\
Parameters of bone remodeling & 2 & $1-5$ \\
Decreased hypertrichosis & 1 & $1-2$ \\
X-Ray & & \\
\hline
\end{tabular}




\section{CHAPTER 4}

Complex Regional Pain Syndrome 1 The Swiss cohort study 


\section{Abstract}

Background Little is known about the course of Complex Regional Pain Syndrome 1 and potential factors influencing the course of this disorder over time. The goal of this study is a) to set up a database with patients suffering from suspected CRPS 1 in an initial stadium, b) to perform investigations on epidemiology, diagnosis, prognosis, and socioeconomics within the database and c) to develop a prognostic risk assessment tool for patients with CRPS 1 taking into account symptomatology and specific therapies.

Methods/design Prospective cohort study. Patients suffering from a painful swelling of the hand or foot which appeared within $\mathbf{8}$ weeks after a trauma or a surgery and which cannot be explained by conditions that would otherwise account for the degree of pain and dysfunction will be included. In accordance with the recommendations of International Classification of Functioning, Disability and Health (ICF model), standardised and validated questionnaires will be used. Patients will be monitored over a period of 2 years at 6 scheduled visits ( 0 and 6 weeks, 3, 6, 12, and 24 months). Each visit involves a physical examination, registration of therapeutic interventions, and completion of the various study questionnaires. Outcomes involve changes in health status, quality of life and costs/utility.

Discussion This paper describes the rationale and design of patients with CRPS 1. Ideally, potential risk factors may be identified at an early stage in order to initiate an early and adequate treatment in patients with increased risk for delayed recovery. 


\section{Background}

Complex Regional Pain Syndrome (CRPS) is a painful condition with clinical features that include pain, sensory-, sudomotor and vasomotor disturbances, trophic changes and impaired motor function [1]. Symptoms usually appear after an initiating noxious event such as trauma or surgery $[2,3]$. The course varies from mild and self-limiting to chronic disease with a high impact on daily functioning and quality of life [4]. CRPS is often associated with a significant morbidity and loss of quality of life [5]. Just recently, Duman et al. reported that in Turkey almost a third of patients with CRPS are not returning to work [6]. In a retrospective chart review of 143 patients with CRPS who had been assessed and/or treated at a universitybased pain centre in the United States, over half of all patients were involved in worker compensation claims [7] and a fifth of all patients in law suits [7].

Information regarding relevant prognostic factors in CRPS is sparse or difficult to interpret, due to the specificity of circumstances in which the information was collected [8]. For the initiation of CRPS 1 certain psychological characteristics such as depression, recent life events or emotional instability are considered to be prognostic factors [9]. The nature and severity of the initiating event does not seem to have a prognostic value on the course of the disease [10]. In the literature, the following parameters have been identified as prognostic factors for delayed recovery: duration of the complaints (more than 90 days), cold CRPS 1, passive coping style and poor controllability of the complaints $[11,12]$.

The goal of this study is a) to set up a database with patients suffering from suspected CRPS 1 in an initial stage, b) to perform investigations on epidemiology, diagnosis, prognosis, and socioeconomics within the database and c) to develop a prognostic risk assessment tool for patients with CRPS 1 taking into account symptomatology and specific therapies. Ideally, risk factors are recognized that are present early in the disease course so that patients with increased risk for delayed recovery can be identified early and treated adequately to minimize persistent pain and functional disability.

\section{Methods/Design}

\section{Study design}

The prospective cohort study follows an observational study design with a consecutive registration of patients with CRPS 1 for two years. Thereafter, we intend to extend the follow up of this cohort pending on further funding. 


\section{Study population}

We will include all consenting eligible patients suffering from a painful swelling of the hand or foot which appeared within 8 weeks after a trauma or a surgery and which cannot be explained by conditions that would otherwise account for the degree of pain and dysfunction.

\section{Inclusion criteria}

Painful swelling of the hand or foot which appeared within 8 weeks after a trauma or a surgery and which cannot be explained by conditions that would otherwise account for the degree of pain and dysfunction.

- One single extremity is affected.

- $\quad$ Sings and symptoms are still present at first visit.

- Patients able to attend follow-up visits at Balgrist University Hospital, Zurich, Switzerland.

- $\quad$ Age limit 18 years or older.

- Signed informed consent.

\section{Rationale for inclusion criteria}

Our inclusion criteria are set very broadly. This allows us to distinguish between those subjects with CRPS like manifestations and others fulfilling diagnostic criteria of current classification systems. This approach has several advantages. First we are able to develop statistical tools to identify manifestational profiles that are unlikely to develop CRPS. Moreover we are able to study differences in the prognosis of patients with CRPS like symptoms from patients fulfilling the CRPS criteria. Finally, our over inclusive enrolment has the potential to inform new classification systems for CRPS with a focus on prognosis rather than diagnosis.

\section{Exclusion criteria}

- Other conditions which appeared before the initiating event or which can explain signs and symptoms better than CRPS 1.

- Signs and symptoms on more than one extremity.

- Gravidity, lactation.

\section{National and international collaboration}

After an initial period, we plan collaboration with other Swiss national medical centres and societies from medical specialists, insurance companies and patient societies. Internationally, we collaborate with the Trauma Related Neuronal dysfunction (TREND) research consortium from the Netherlands [13]. 


\section{Procedure}

We will recruit participants through direct referral from primary care physicians and medical specialists in physical medicine \& rehabilitation, rheumatologists, neurologists, pain specialists and orthopaedic surgeons. FB, UW and RK perform the screening visit with possible participants. Subjects who meet the eligibility criteria will receive further information concerning the study. In particular, the aims and methods will be explained after which written consent to participate will be sought. This trial has been approved by the local Ethics Committee of Balgrist University Hospital (Spezialisierte Unterkomission für Orthopadie der Kantonalen Ethikkommission, Zurich, Switzerland, reference number EK01/2008).

Assessments will be performed after 6 weeks, 3 months, 6 months, 12 months, 18 months and 24 months. The study follows a strictly observational design in which the therapeutic intervention will be registered and classified according to the list below (see table 1) and treatment effects will be recorded for several health related outcomes. The focus will be on observing the course of the disorder over time and to identify significant risk factors that may change the course in a positive or negative way. Patients undergo individual treatment protocols based on best current internationally accepted guidelines [14-16]. In order to exclude other underlying causes that may account for the degree of pain or limitation exhibited by the patient, additional laboratory tests or imaging methods will be performed at the discretion of the physician. However, a minimal set of diagnostic tests will be obtained in every participants (C-reactive protein and conventional x-ray of both hands respectively feet). To determine the positive diagnosis of CRPS 1 we will use the IASP criteria [17]. Simultaneously, we will collect a broad set of CRPS associated signs and symptoms. This additional information will help us to classify the patients according to other diagnostic criteria sets (e.g. [10], [18], [19]) and allows us to perform future adaptations due to changing concepts in CRPS taxonomy.

Table 1: Categories of treatment

\section{Pharmacological treatment:}

Topical medications: Topical anaesthetics, topical capsaicin

Oral medications: Acetaminophen, NSAR, opioids, antidepressants, anticonvulsive medications

Other medications: Corticosteroids, calcitonin, bisphosphonates, vitamin c, nifedipin

\section{Interventional therapies:}

Sympathetic blockades, intravenous regional anaesthetic blocks, intravenous blocks, other blocks, neurolytic sympathetic blocks

Implanted therapies:

Peripheral nerve stimulation, spinal cord stimulator

Functional restoration:

Physical therapy, occupational therapy

Behavioural therapy:

Cognitive therapy, behavioural therapy 


\section{Safety monitoring and adverse events}

Since this study follows an observational design without an actual intervention there is no substantial risk associated with participation. There is no additional physical and physiological discomfort to be expected with participation. However, any unexpected events and adverse events will be registered and followed. The investigator will take care that all subjects are kept informed. All adverse events will be followed until they have abated, or until a stable situation has been reached. Depending on the event, follow up may require additional tests or medical procedures as indicated, and/or referral to the primary care physician or a medical specialist.

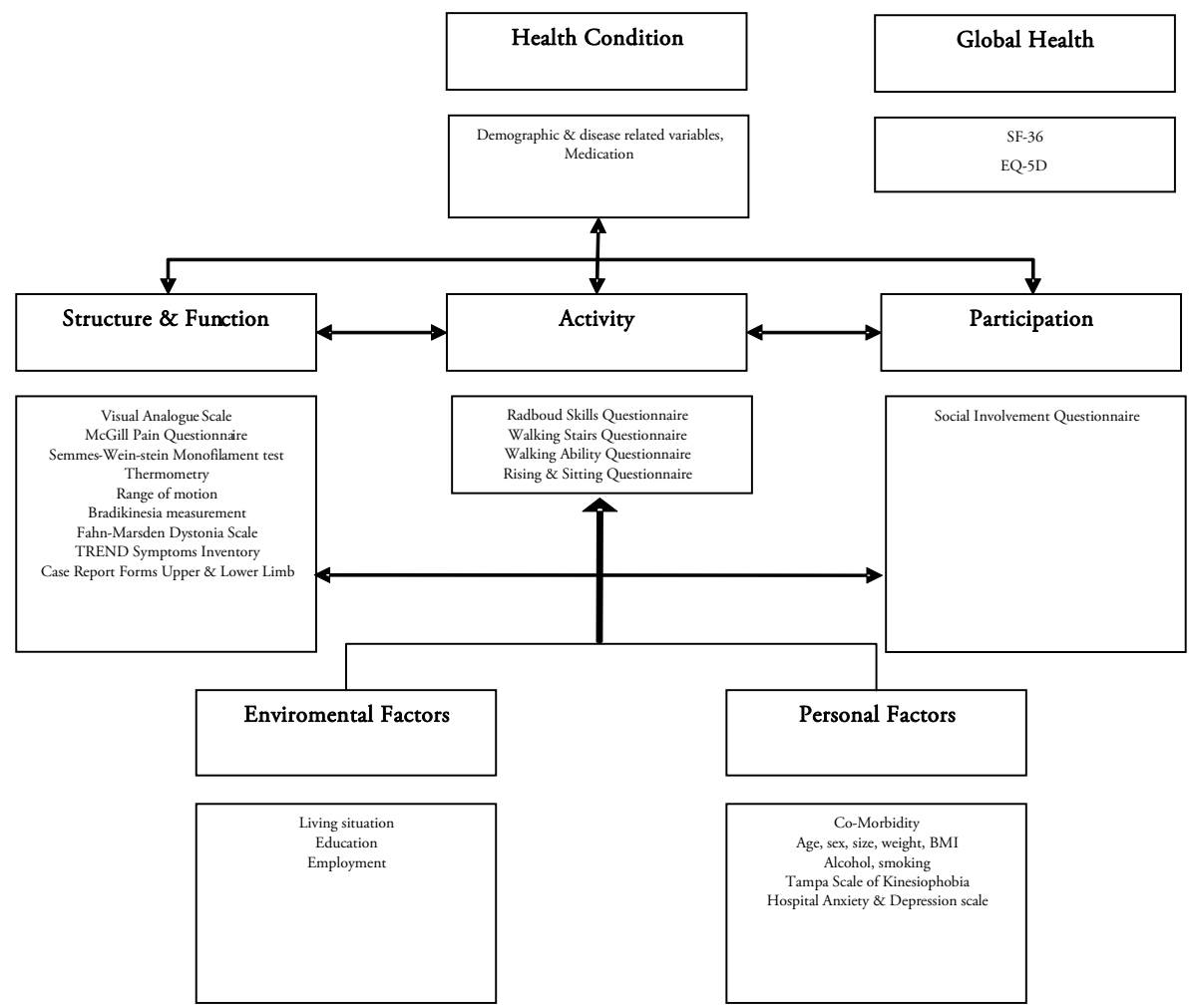

Figure 1 outlines the way how we will evaluate the health status of the participants.

Outcome measures (baseline \& follow up)

The assessments were chosen in order to cover the domains as described in the ICF model [20]. The consequences of CRPS 1 will be monitored at different levels such as body structure and function, activity and participation as well as contextual factors influencing a person's health condition. Table 2 summarizes the instrument used per evaluation point. 
Table 2: Outcome measures (adapted from [8])

\begin{tabular}{|c|c|c|c|c|c|c|}
\hline Assessments and Instruments & Baseline & $\begin{array}{c}6 \\
\text { weeks }\end{array}$ & $\begin{array}{c}3 \\
\text { months }\end{array}$ & $\begin{array}{c}6 \\
\text { months }\end{array}$ & $\begin{array}{c}12 \\
\text { months }\end{array}$ & $\begin{array}{c}24 \\
\text { months }\end{array}$ \\
\hline \multicolumn{7}{|l|}{ Baseline Variables } \\
\hline Demographic variables & $x$ & $x$ & $x$ & $\mathrm{x}$ & $x$ & $x$ \\
\hline Disease related variables & $x$ & & & & & \\
\hline Medication & $\mathrm{x}$ & $\mathrm{x}$ & $\mathrm{x}$ & $\mathrm{x}$ & $\mathrm{x}$ & $\mathrm{x}$ \\
\hline Intoxication (smoking, alcohol) & $\mathrm{x}$ & & & & & \\
\hline
\end{tabular}

Body Structure and Functions

Pain

VAS diary pain

Mc Gill pain questionnaire

Sensory symptoms

Sensory testing [22]

Vasomotor

Thermometry [23]

Sudomotor/edema

Indirect volumetry [24]

Motor/trophic

Range of motion [25]

Dystonia (Fahn Marsden Scale) [26] ${ }^{+}$

TREND Symptoms Inventory [27]

\section{Participation}

Radboud Skills Questionnaire [28]*。

Walking Ability Questionnaire [29]" 。

Rising \& Sitting Ability Questionnaire [30]"

Participation

Social Involvement Questionnaire [31]

Global Outcomes

SF-36 [32]

EQ-5D [33]

Environmental factors

Living situation, education, employment

\section{Personal Factors}

Tampa Scale of Kinesiophobia [34]

Hospital Anxiety \& Depression scale [35]

Co-Morbidity [36]

$\begin{array}{llllll}x & x & x & x & x & x \\ x & x & x & x & x & x\end{array}$

$\begin{array}{llllll}\mathbf{x} & \mathbf{x} & \mathrm{x} & \mathrm{x} & \mathrm{x} & \mathbf{x}\end{array}$

$\begin{array}{lllll} & x & x & x & x\end{array}$

$\begin{array}{llllll}x & x & x & x & x\end{array}$

$\begin{array}{llllll}x & x & x & x & x & x\end{array}$

$\begin{array}{llllll}x & x & x & x & x & x\end{array}$

+The Fahn Marsden Score will only be used in patients with clinical signs of dystonia.

*Only in patients with CRPS 1 in the upper extremity.

" Only in patients with CRPS 1 in the lower extremity.

${ }^{\circ}$ These questionnaires will be validated in German as a side project. 


\section{Socioeconomic Analysis}

\section{Cost analysis}

Both direct health care costs, direct non-healthcare costs (patient cost) and indirect cost (productivity losses) will be included in the analysis. Direct health care costs include the costs of the diagnostic and prognostic trajectory and staff time (primary care physicians, specialists in physical medicine \& rehabilitation, rheumatology, neurology, pain specialists and orthopaedic surgeons.). Volumes will be collected using existing registration systems and cost diaries. Non-medical costs such as productivity losses, time and travel costs and other out-of-pocket costs for undergoing diagnostic procedures or treatment will be registered using cost diaries. This diary will be handed over to patients upon their first visit. Cost calculation will be based on real prices or on unit prices from the Swiss Guideline for Cost Calculation. In case of household activities, or other unpaid activities foregone, shadow prices will be used.

\section{Sample size}

Since this is a consecutive registration of eligible patients, a sample size calculation is not necessary. After enrolling the first 100 patients, we perform an internal quality assessment and, if necessary, perform procedural changes. When the value of a combination of several variables needs to be quantified no straight forward methods to estimate the required sample size are available. A frequently used "rule of thumb" recommends that for each variable included in the analysis, at least 10 patients with a positive outcome (in this case the resolution of symptoms or other outcomes) are necessary [21]. Based on the assumption that about one third of patients will not return to work (indicating chronification) and the assessment of about 30 covariates we will need to enroll about 700 patients.

\section{Statistical analysis}

Epidemiologic data and patient characteristics available on continuous scales will be presented with medians and interquartile ranges or means and standard deviations as appropriate. Categorical data will be presented as rates and percentages. Associations between individual (independent) variables and the outcome variables will be reported using correlation coefficients. Results from univariate analysis will inform multivariate modeling.

Assessment of causal associations will be performed using multivariate models including potential confounders along with the independent variables of interest. Prognostic scores will be built using either multivariate logistic regression analysis or Cox proportional hazard models. Models will be validated in cross samples. Calibration and discrimination of the Cross validated prognostic instruments will be assessed using the Brier Score. Missing data will be imputed using multiple imputation methods if the assumption that missingness is at random seems justifiable. 


\section{Discussion}

This paper describes the rationale and design of a prospective cohort study following the course of CRPS 1 . We intend to set-up a prospectively acquired clinical database for two years. To our knowledge this is the first attempt to set up a prospective cohort study with CRPS 1 patients.

We believe that the project is timely. From a socioeconomic and epidemiological perspective many questions regarding CRPS remain unanswered. While considerable efforts have gone into basic science research dealing with pathogenesis of CRPS the clinical counterpart has not been vigorously fostered. Among the few examples we are aware of the Dutch consortium Trend which established a registry of cases with CRPS 1 . We think that our collaboration with this group has a significant synergistic capacity. Our partnership will contribute to a better understanding of many important aspects of CRPS and inform the future research agenda in this area. It is likely to generate considerable transfer value to the health care system not only because its results will have a direct impact on patient care but also because it allows identifying patients requiring particular attention and care. Finally, we believe that this study will guide investigators to set the research agenda in this rapidly evolving field. 


\section{References}

1. Bruehl S, Harden RN, Galer BS, Saltz S, Backonja M, Stanton-Hicks M: Complex regional pain syndrome: are there distinct subtypes and sequential stages of the syndrome? Pain 2002, 95(12):119-124.

2. de Mos M, de Bruijn AG, Huygen FJ, Dieleman JP, Stricker BH, Sturkenboom MC: The incidence of complex regional pain syndrome: a population-based study. Pain 2007, 129(1-2):12-20.

3. Sandroni P, Benrud-Larson LM, McClelland RL, Low PA: Complex regional pain syndrome type I: incidence and prevalence in Olmsted county, a population-based study. Pain 2003, 103(1-2):199207.

4. Galer B, Schwartz L, Allen R: Complex regional pain syndromes - Type I: reflex sympathetic dystrophy, and Type II: causalgia. In: Bonica's Management of Pain. Edited by JD L. Philadelphia: Lippincott, Williams \& Wilkins; 2000: 388-411.

5. Bär E, Felder M, Kiener B: Algodystrophie. Luzern: Schweizerische Unfallversicherungsgesellschaft; 1998.

6. Duman I, Dincer U, Taskaynatan MA, Cakar E, Tugcu I, Dincer K: Reflex sympathetic dystrophy: a retrospective epidemiological study of 168 patients. Clin Rheumatol 2007, 26(9):1433-1437.

7. Allen G, Galer BS, Schwartz L: Epidemiology of complex regional pain syndrome: a retrospective chart review of 134 patients. Pain 1999, 80(3):539-544.

8. Perez RS, Van Hilten JJ, Marinus J: TREND: Source document 1 - Study designs and outcomes (Version 5). 2007.

9. Geertzen $\mathrm{JH}$, de Bruijn H, de Bruijn-Kofman AT, Arendzen JH: Reflex sympathetic dystrophy: early treatment and psychological aspects. Arch Phys Med Rehabil 1994, 75(4):442-446.

10. Veldman PH, Reynen HM, Arntz IE, Goris RJ: Signs and symptoms of reflex sympathetic dystrophy: prospective study of 829 patients. Lancet 1993, 342(8878):1012-1016.

11. Perez RS, Brum PE, Rijnsburger ER, Zuurmond WA, de Lange JJ: Predictive value of pain, temperature, volume and range of motion in complex regional pain syndrome type 1 . Anaesthesiology 2001(95):A803.

12. Perez RS, Zuurmond WW, Bezemer PD, Kuik DJ, van Loenen AC, de Lange JJ, Zuidhof AJ: The treatment of complex regional pain syndrome type I with free radical scavengers: a randomized controlled study. Pain 2003, 102(3):297-307.

13. Perez RS, Van Hilten JJ, Marinus J: Trauma RElated Neuronal Dysfunction Consortium. http://www.trendconsortium.nl/.

14. Geertzen JHB, Perez RSGM, Dijkstra PU, Kemler MA, Rosenbrand CJGM: Complex regional pain syndrome 1 guidelines. In. Edited by Specialists NSoR, Anaesthesiologists NSo. Alphen an den Rjin: Van Zuiden Communications B.V.; 2006.

15. Harden N (ed.): Complex regional pain syndrome: treatment guidelines. Milford, CT: RSDSA Press; 2006.

16. Stanton-Hicks M, Baron R, Boas R, Gordh T, Harden N, Hendler N, Koltzenburg M, Raj P, Wilder R: Complex Regional Pain Syndromes: guidelines for therapy. Clin J Pain 1998, 14(2):155-166.

17. Merskey $\mathrm{H}$, Bogduk $\mathrm{N}$ : Classification of chronic pain: description of chronic pain syndrome and definitions of pain terms., 2nd. edn. Seatle: IASP Press; 1994.

18. Bruehl S, Harden RN, Galer BS, Saltz S, Bertram M, Backonja M, Gayles R, Rudin N, Bhugra MK, Stanton-Hicks M: External validation of IASP diagnostic criteria for Complex Regional Pain Syndrome and proposed research diagnostic criteria. International Association for the Study of Pain. Pain 1999, 81(1-2):147-154.

19. Harden RN, Bruehl S, Stanton-Hicks M, Wilson PR: Proposed new diagnostic criteria for complex regional pain syndrome. Pain Med 2007, 8(4):326-331.

20. WHO: ICIDH: International Classification of Impairments, Disabilities and Handicaps. Geneva; 1980. 
21. Peduzzi P, Concato J, Kemper E, Holford TR, Feinstein AR: A simulation study of the number of events per variable in logistic regression analysis. J Clin Epidemiol 1996, 49(12):1373-1379.

22. Rommel O, Gehling M, Dertwinkel R, Witscher K, Zenz M, Malin JP, Janig W: Hemisensory impairment in patients with complex regional pain syndrome. Pain 1999, 80(1-2):95-101.

23. Feldman F, Sherman RA, Barja RH, Bruno GM: Thermography of the hand and wrist: practical applications. Hand Clin 1991(7):99-112.

24. Bednarczyk JH, Hershler C, Cooper DG: Development and clinical evaluation of a computerized limb volume measurement system (CLEMS). Arch Phys Med Rehabil 1992(73):60-63.

25. Ryf C, Weymann A: AO Neutral-O Methode, Messung und Dokumentation. Stuttgart: George Thieme Verlag; 1999.

26. Burke E, Fahn S, Marsden D, Bressman B, Moskowitz C, Friedman J: Validity and reliability of a rating scale for the primary torsion dystonias. Neurology 1985, 35:73-77.

27. Collins S, van Hilten JJ, Marinus J, Zuurmond WW, de Lange JJ, Perez RS: Development of a Symptoms questionnaire for Complex Regional Pain Syndrome and potentially related illnesses: the TREND Symptoms Inventory. Arch Phys Med Rehabil 2008, accepted.

28. Oerlemans HM, Cup EH, DeBoo T, Goris RJ, Oostendorp RA: The Radboud skills questionnaire: construction and reliability in patients with reflex sympathetic dystrophy of one upper extremity. Disabil Rehabil 2000, 22(5):233-245.

29. Roorda LD, Roebroeck ME, van Tilburg T, Molenaar IW, Lankhorst GJ, Bouter LM, Boonstra AM, de Laat FA, Caron JJ, Burger BJ, Heyligers IC, Nollet F, Stover-Van Herk IE, Perez RS, Meijer JW, Rijken PM; Measuring Mobility Study Group.: Measuring activity limitations in walking: development of a hierarchical scale for patients with lower-extremity disorders who live at home. Arch Phys Med Rehabil 2005, 86(12):2277-2283.

30. Roorda LD, Molenaar IW, Lankhorst GJ, Bouter LM: Improvement of a questionnaire measuring activity limitations in rising and sitting down in patients with lower-extremity disorders living at home. Arch Phys Med Rehabil 2005, 86(11):2204-2210.

31. Van Dam-Baggen R, Kraaimaat F: De Inventarisatielijst Sociale Betrokkenheid (ISB): een zelfbeoordelingstlijst om sociale steun te meten. Gedragstherapie 1992, 25(1):25-46.

32. Ware JE, Jr., Sherbourne CD: The MOS 36-item short-form health survey (SF-36). I. Conceptual framework and item selection. Med Care 1992, 30(6):473-483.

33. von der Schulenburg JM, Claes C, Greiner W: Die deutsche Version des EuroQol-Fragebogens. Z Gesundheitswissenschaften 1998, 6:3-20.

34. Vlaeyen JW, Linton SJ: Fear-avoidance and its consequences in chronic musculoskeletal pain: a state of the art. Pain 2000, 85(3):317-332.

35. Zigmond AS, Snaith RP: The hospital anxiety and depression scale. Acta Psychiatr Scand 1983, 67(6):361-370.

36. Sangha O, Stucki G, MH. L, Fossel AH, Katz JN: The Self-Administered Comorbidity Questionnaire: a new method to assess comorbidity for clinical and health senvices research. Arthritis Rheum 2003, 49(2):156-163. 



\section{CHAPTER 5}

German translation and external validation of the Radboud Skills Questionnaire in patients suffering from CRPS 1 


\section{Abstract}

Background Patients suffering from Complex Regional Pain Syndrome commonly complain of substantial limitations in their activities of daily living. The Radboud Skills Questionnaire measures alterations in the level of disability of patients with Complex Regional Pain Syndrome, but this instrument is currently not available in German.

Objective The goals of our study were to translate the Dutch Radboud Skills Questionnaire into German and to assess its external criterion validity with the German version of the Disabilities of the Arm, Shoulder and Hand Questionnaire.

Methods/Design We translated the Radboud Skills Questionnaire according to published guidelines. Demographic data and validity were assessed in 57 consecutive patients with Complex Regional Pain Syndrome 1 of the upper extremity. Information on age, duration of symptoms, type of Complex Regional Pain Syndrome 1 and type of initiating event was obtained. We assessed the external criterion validity by comparing the German Radboud Skills Questionnaire and the German Disabilities of the Arm, Shoulder and Hand Questionnaire and calculated the prediction intervals.

Results Score values ranged from $96.4 \pm 26.0$ for the Disabilities of the Arm, Shoulder and Hand Questionnaire score and 140.1 \pm 39.2 for the Radboud Skills Questionnaire. We found a high agreement between the Radboud Skills Questionnaire and the Disabilities of the Arm, Shoulder and Hand Questionnaire $\left(R^{2}=0.84\right)$.

Conclusion This validation of the Radboud Skills Questionnaire demonstrates that this German version is a simple and reliable instrument to assess and quantify disabilities of patients suffering from CRPS 1 of the upper extremity for clinical and research purposes. 


\section{Background}

Most of the measurement instruments that assess the condition of patients suffering from Complex Regional Pain Syndrome (CRPS) focus on impairments on a structural and functional level [1-6]. So far, activity limitations have not been evaluated as extensively as the impairments caused by CRPS. As a consequence, little information is available on the problems CRPS patients encounter in activities of daily living.

One global instrument to assess symptoms and functional status of the upper extremity is the Disabilities of the Arm, Shoulder and Hand Questionnaire (DASH) [7]. The DASH has been validated in German [8] and is widely used in clinical practice and research to measure activity and limitations in patients with upper extremity musculoskeletal conditions including CRPS [8]. One of the advantages of the self-administered DASH is that it includes symptoms and disabilities of the whole upper extremity and that it can be applied in a broad range of disorders. However, methodological work has shown that disease-specific questionnaires are generally more responsive to change and that they are more relevant to patients than global instruments [9].

The Radboud Skills Questionnaire (RASQ) [10] is a valid instrument for measuring alterations in the level of functional tasks of the upper extremity that has been developed specifically for patients with CRPS. The original version of this questionnaire is in Dutch. Our aim was to translate the RASQ into German and to verify its external validity by comparing it with the German version of the DASH $\left(\mathrm{DASH}_{\mathrm{G}}\right)$.

\section{Materials and Methods}

\section{Recruitment sources and data acquisition}

We recruited patients from the outpatient clinic of Balgrist University Hospital, Zurich, Switzerland and through advertisements posted on two self-help homepages for patients afflicted with CRPS (www.morbus-sudeck.ch, http://sudeck.forencity.de). We included all eligible and consenting adult patients suffering from CRPS 1 of the upper extremity with fulfilled IASP criteria [11], age more than 18 years of age, illness duration of more than three months and the ability to complete the questionnaires. The study protocol was approved by the local Ethics Committee and informed consent was obtained from all participants. 


\section{Assessment instruments}

In 1999, Oerlemans et al. constructed and validated the RASQ to measure the level of disability in activities of daily living in patients with CRPS 1 of the upper extremity [10].

The questionnaire construction was based on the Dutch elaboration of the International Classification of Impairments, Disabilities and Handicaps, an earlier version of the ICF model [12]. The questionnaire contains items of 'disabilities due to hand disease' domain of the ICF model. In order to be applied to both hands, the questionnaire includes items referring to two-handed activities in daily living or social activities. The constructed questionnaire was judged for its merit in Delphi rounds with experts and then readjusted. The original version of the RASQ questionnaire consists of 11 categories, with the first four addressing personal care (15 questions), the next three addressing domestic activities (17 questions) and the latter four addressing other activities (13 questions). The RASQ was reliable in terms or response stability (median coefficients of variation 2.2 to $6.6 \%$ ) and the correlations between categories of items were fair to good [10]. A numeric score (1-5, with an extra score of '9' for 'not applicable' for patients who never perform the involved activity) is assigned to each questions of the RASQ. In order to avoid implications on the scores, we scored every missing or not applicable response with the mean score of the specific question. The Disabilities of the Arm, Shoulder and Hand Questionnaire (DASH) questionnaire is a standardized patient-completed upper extremity outcome measure [7]. Using a self-reporting system, patients choose scores of on to five to 30 items relating to impairments and activity limitations, as well as participation restrictions in leisure activities and work. The raw score is transformed to a 0-100 scale, where 0 reflects minimum and 100 maximum disability. The DASH questionnaire was translated in many languages. The German questionnaire was obtained from http://www.dash.iwh.on.ca.

\section{Translation process}

We followed a sequential forward and backward translation approach (see figure 1) [13]. Two professional translators translated the original Dutch version of the RASQ into German. In a consensus meeting a rheumatologist, a specialist in physical medicine and rehabilitation, a physical therapist and an epidemiologist assessed the consistency of the translation and judged its face validity. They then agreed on the first German version for these formats. The questionnaire was pilot tested in five CRPS 1 patients to identify difficulties in comprehension and interpretation of the questions. In addition, we tested various possible wordings of items, answer choices and instructions if the translation team considered more than one possible version. A Dutch translator with experience in biomedical sciences but unaware of the original versions performed a back translation of the German version into the source language (Dutch). A team of experts (a rehabilitation specialist, a rheumatologist, an epidemiologist and a physical therapist) compared the back translation 
with the Dutch versions to check for conceptual discrepancies. After a second pilot test ( $n=5$ CRPS patients), the translation team discussed the comments from these patients and decided by consensus on modifications. Finally, the experts approved the final German version of the RASQ (RASQ ${ }_{G}$ ) (Appendix).

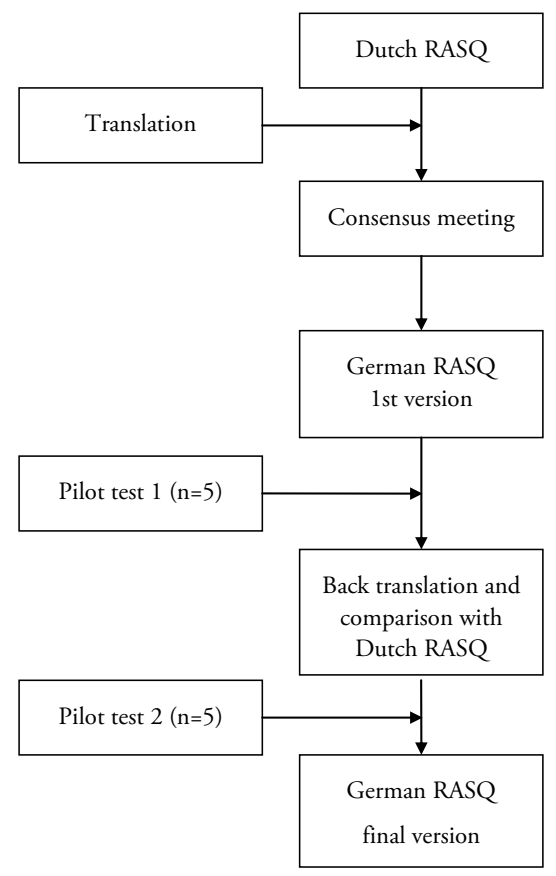

Figure 1: Flow diagram of the development process of the German RASQ

Validity assessments

Both questionnaires were offered to CRPS patients meeting the inclusion criteria. Based on formal sample size calculations for regression analysis the required number of patients for the validity assessment was established at 50. Patients received both questionnaires either during a visit to our outpatient clinic or by mail. Participants were asked to complete both questionnaires on the same day and to mail them back to our institution.

\section{Statistical analysis}

Values are reported as mean $\pm \mathrm{SD}$, medians and interquartile ranges (where appropriate) or as absolute number and percentage. Linear regression analysis and individual prediction intervals were used to assess the relationship between the RASQ $_{G}$ and the German DASH questionnaire $\left(D A S H_{G}\right)$. A probability value of $p<0.05$ was considered statistically significant for all tests. Data storage and statistical analyses were performed with the SPSS 12 statistical software package. (SPSS Inc. Headquarters, 233 S. Wacker Drive, 11th floor Chicago, Illinois 60606). 


\section{Results}

Translation and instrument development

The wording of the questions and response options correspond to the original version. We did not add or remove items nor changed the response categories.

Demographic and clinical characteristics

The demographic and clinical characteristics of the participants are shown in table 1. We enrolled 57 patients suffering from CRPS of the upper extremity in this study (female/male 37/20). Surgery was the most common initiating event (54.4\%). Median disease duration was 1.9 years (IQR 0.9 to 4.3). Average score for the $\mathrm{RASQ}_{\mathrm{G}}$ was $140.1+39.2$ and for the $\mathrm{DASH}_{\mathrm{G}} 96.4+26.0$.

Table 1: Characteristics of study population $(\mathrm{N}=57)$

\begin{tabular}{|c|c|}
\hline \multicolumn{2}{|l|}{ Gender } \\
\hline Male & $20(35.1 \%)$ \\
\hline Female & $37(64.9 \%)$ \\
\hline Mean age ( \pm standard deviation) & $53.4 \pm 11.8$ years \\
\hline Age range & $21.2-81.8$ years \\
\hline Median number of years with CRPS 1* & 1.9 years ( 0.9 to 4.3$)$ \\
\hline \multicolumn{2}{|l|}{ Initiating event } \\
\hline Trauma & $21(36.8 \%)$ \\
\hline Surgery & $31(54.4 \%)$ \\
\hline Other & $5(8.8 \%)$ \\
\hline RASQ $_{\text {German }}{ }^{+}$ & $140.1 \pm 39.2$ \\
\hline DASH $_{\text {German" }}$ & $96.4 \pm 26.0$ \\
\hline
\end{tabular}

High agreement between the $R A S Q_{G}$ and the $D A S H_{G}$

We found a high agreement between the $\mathrm{RASQ}_{G}$ and the $\mathrm{DASH}_{G}\left(\mathrm{R}^{2}=0.84\right)$. The regression function showed an intercept of 11.71 and a slope of 0.60 . Figure 2 shows the $95 \%$ prediction intervals and the regression line. 


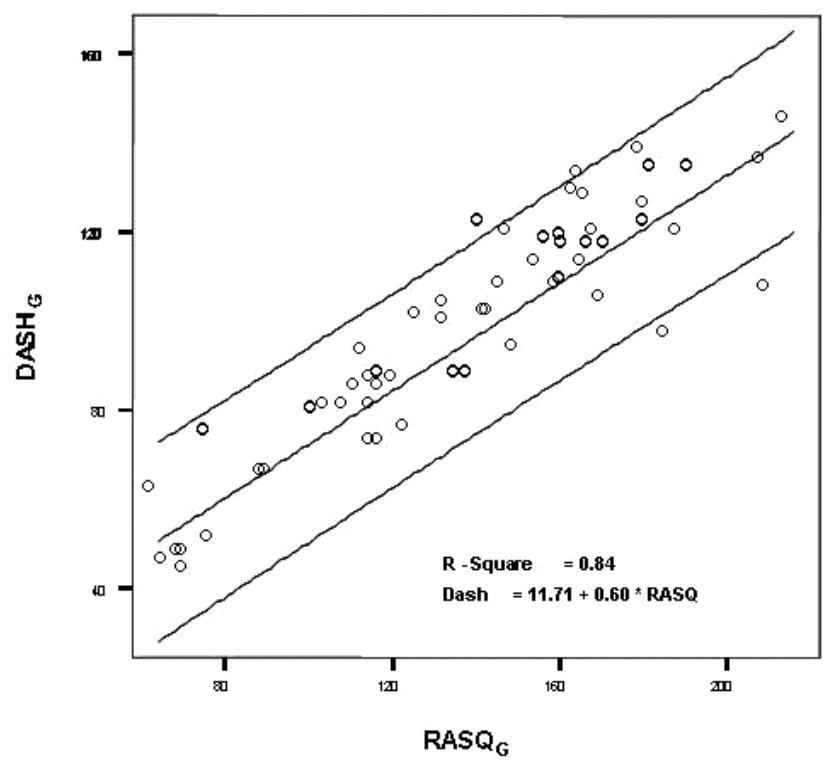

Figure 2: Linear regression line with 95\% prediction intervals for an individual

\section{Discussion}

To our knowledge, this is the first German translation and external validation of the originally Dutch version of the RASQ, allowing the standardized measurement of activity limitations of patients suffering from CRPS of the upper extremity. We found that the disease-specific German RASQ $\left(\mathrm{RASQ}_{\mathrm{G}}\right)$ had excellent agreement with the global German DASH $\left(\mathrm{DASH}_{\mathrm{G}}\right)$ questionnaire. Given its higher theoretical potential to detect changes in disability (responsiveness) we propose that the disease-specific RASQ should be the instrument of choice when assessing patients with CRPS of the upper extremity.

The translation process itself had no issues of concern, all forward and backward translations were consistent with each other and with the original version. We followed the rigorous translation method proposed by Wild et al. [14], which consisted of a forward and backward translation by professional translators, and by a consensus meeting between researchers. By applying this robust methodology we ensured that the content, integrity and essence of the RASQ items are maintained and expressed clearly and accurately from one language to another.

Our study has several limitations. First, since diagnosis of CRPS is still a matter of debate our sample might not be representative for a larger CRPS population. The diagnosis of CRPS is based on clinical findings (including sensory, autonomic, motor and trophic changes) and the fulfilment of established diagnostic criteria 
[15]. We only included patients fulfilling the criteria established by the International Association for the Study of Pain (IASP) [11] in all participants. However, these IASP criteria have been criticized because they are symptom based and show a low specificity [16]. Second, the RASQ is an instrument characterized by measuring functioning as perceived and recalled by the participants. In a study by Schasfoort et al. the authors showed that activity of the upper extremity measured by an upper limb activity monitor only had a weak or non-specific relationship with the RASQ and other similar instruments, including the DASH [17]. This indicates that the actual activity potentially differs from measuring perceived functioning in questionnaires. However, we do not think that this is an actual limitation of the study, since it has been shown that the correlation between impairment and disability is generally only weak to moderate [18].

This validated German version of the RASQ will help determine disability in patients suffering from CRPS 1 of the upper extremity in German speaking countries and is appropriate for clinical practice as well as research. In addition, it allows for a comparison of the results of studies from different countries. In particular, the German version of the RASQ allows us now to collect data for the Swiss CRPS cohort study [19] and to compare the results with those of our Dutch collaborator in the TREND consortium [20]. Investigators in German-speaking countries now have the possibility to assess physical activity and limitations in daily living in patients with CRPS of the upper extremity using the German RASQ.

In conclusion, the assessment of disability is essential for the management of patients suffering from CRPS. Disability may negatively interact with performance levels and outcome measures, and therefore needs to be taken into consideration when caring for these patients. This validation of the RASQ demonstrates that this German version is a simple and valid instrument to assess and quantify disability of patients suffering from CRPS 1 of the upper extremity for clinical and research purposes. 


\section{References}

1. Veldman PH, Reynen HM, Arntz IE, Goris RJ: Signs and symptoms of reflex sympathetic dystrophy: prospective study of 829 patients. Lancet 1993, 342(8878):1012-1016.

2. Price DD, Long $\mathrm{S}$, Huitt C: Sensory testing of pathophysiological mechanisms of pain in patients with reflex sympathetic dystrophy. Pain 1992, 49(2):163-173.

3. Davidoff G, Morey K, Amann M, Stamps J: Pain measurement in reflex sympathetic dystrophy syndrome. Pain 1988, 32(1):27-34.

4. Cronin KD, Kirsner RL, Fitzroy VP: Diagnosis of reflex sympathetic dysfunction. Use of the skin potential response. Anaesthesia 1982, 37(8):848-852.

5. Greco F, De Palma L, Specchia N, Mannarini M, Gigante A: The role of instrumental diagnostic methods in the staging of Sudeck's disease. Acta Orthop Belg 1993, 59(4):344-351.

6. Karstetter KW, Sherman RA: Use of thermography for initial detection of early reflex sympathetic dystrophy. J Am Podiatr Med Assoc 1991, 81(4):198-205.

7. Hudak PL, Amadio PC, Bombardier C: Development of an upper extremity outcome measure: the DASH (disabilities of the arm, shoulder and hand) [corrected]. The Upper Extremity Collaborative Group (UECG). Am J Ind Med 1996, 29(6):602-608.

8. Westphal T: [Reliability and responsiveness of the German version of the Disabilities of the Arm, Shoulder and Hand questionnaire (DASH)]. Unfallchirurg 2007, 110(6):548-552.

9. Guyatt GH, King DR, Feeny DH, Stubbing D, Goldstein RS: Generic and specific measurement of health-related quality of life in a clinical trial of respiratory rehabilitation. J Clin Epidemiol 1999, 52(3):187-192.

10. Oerlemans HM, Cup EH, DeBoo T, Goris RJ, Oostendorp RA: The Radboud skills questionnaire: construction and reliability in patients with reflex sympathetic dystrophy of one upper extremity. Disabil Rehabil 2000, 22(5):233-245.

11. Merskey $\mathrm{H}$, Bogduk $\mathrm{N}$ : Classification of chronic pain: description of chronic pain syndrome and definitions of pain terms., 2nd. edn. Seattle: IASP Press; 1994.

12. WHO: ICIDH: International Classification of Impairments, Disabilities and Handicaps. Geneva; 1980.

13. Bullinger M: Creating and evaluation cross-cultural instruments. In: Quality of life and pharmacoeconomics in clinical trials. Edited by Spilker B. Philadelphia: Lippincot; 1996: 659-668.

14. Wild D, Grove A, Martin M, Eremenco S, McElroy S, Verjee-Lorenz A, Erikson P: Principles of Good Practice for the Translation and Cultural Adaptation Process for Patient-Reported Outcomes (PRO) Measures: report of the ISPOR Task Force for Translation and Cultural Adaptation. Value Health 2005, 8(2):94-104.

15. Harden R, Bruehl S: Diagnostic criteria: The statistical derivation of the four criterion factors. In: CRPS: Current Diagnosis and Therapy. Edited by Wilson P, Stanton-Hicks M, RN Harden R. Seattle, WA: IASP Press; 2005: 45-58.

16. Bruehl S, Harden RN, Galer BS, Saltz S, Bertram M, Backonja M, Gayles R, Rudin N, Bhugra MK, Stanton-Hicks M: External validation of IASP diagnostic criteria for Complex Regional Pain Syndrome and proposed research diagnostic criteria. International Association for the Study of Pain. Pain 1999, 81(1-2):147-154.

17. Schasfoort FC, Bussmann JB, Stam HJ: Correlation between a novel upper limb activity monitor and four other instruments to determine functioning in upper limb complex regional pain syndrome type I. J Rehabil Med 2005, 37(2):108-114.

18. Hoeymans N, Feskens EJ, van den Bos GA, Kromhout D: Measuring functional status: crosssectional and longitudinal associations between performance and self-report (Zutphen Elderly Study 1990-1993). J Clin Epidemiol 1996, 49(10):1103-1110.

19. Brunner F, Bachmann LM, Weber U, Kessels AG, Perez RS, Marinus J, Kissling R: Complex regional pain syndrome 1--the Swiss cohort study. BMC Musculoskelet Disord 2008, 9:92.

20. Perez RS, Van Hilten JJ, Marinus J: TREND: Source document 1 - Study designs and outcomes (Version 5); 2007. 
Appendix: The German version of the RASQ

\begin{tabular}{|c|c|c|c|c|c|c|}
\hline Durchführung Fertigkeiten & $\begin{array}{l}\bar{Z} \\
\text { हే } \\
\text { z }\end{array}$ & 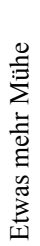 & 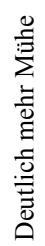 & 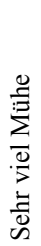 & 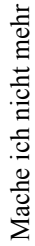 & 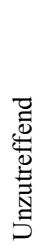 \\
\hline Durchführung von Fertigkeiten & $\mathbb{1}$ & 2 & 3 & $A$ & 5 & (1) \\
\hline
\end{tabular}

\section{A. Persönliche Hygiene}

1. Waschen und Abtrocknen des Ober- und Unterkörpers.

2. Gesichtspflege

(Schminken, Rasieren, Epilieren).

3. Nagelpflege (Finger- und Zehennägel) (schneiden, feilen, evtl. lackieren).

4. Haarpflege (waschen, kämmen, föhnen, hochstecken).

5. Zahnpflege (mit der Hand oder elektrisch, inkl. Zahnpaste auf die Zahnbürste streichen oder Reinigung des Zahnersatzes)......

B. Ankleiden

Oberkörper

6. An- und Ausziehen von Unterwäsche (z. B. BH, Hemd, Korsett)

7. An- und Ausziehen von Oberbekleidung (z. B. Bluse, Pullover, T-Shirt, Krawatte)

Unterkörper

8. An- und Ausziehen von Unterwäsche (z. B. Unterhose, Slip)...

9. An- und Ausziehen von Oberkleidung (z.B. Hose oder Rock).....

10. An- und Ausziehen von Socken oder Strümpfen (inkl. elastischen Strümpfen).....

11. An- und Ausziehen von Schuhen (inkl. das Binden von Schnürsenkeln).

12. Die Handhabung von Verschlüssen (z. B. Knöpfe, Schnallen, Reisverschluss, Manschettenknöpfen, Gürtel).

\section{Selbständig Essen und Trinken}

13. Handhabung von Gabel, Löffel und Messer (Essen zum Mund führen). 


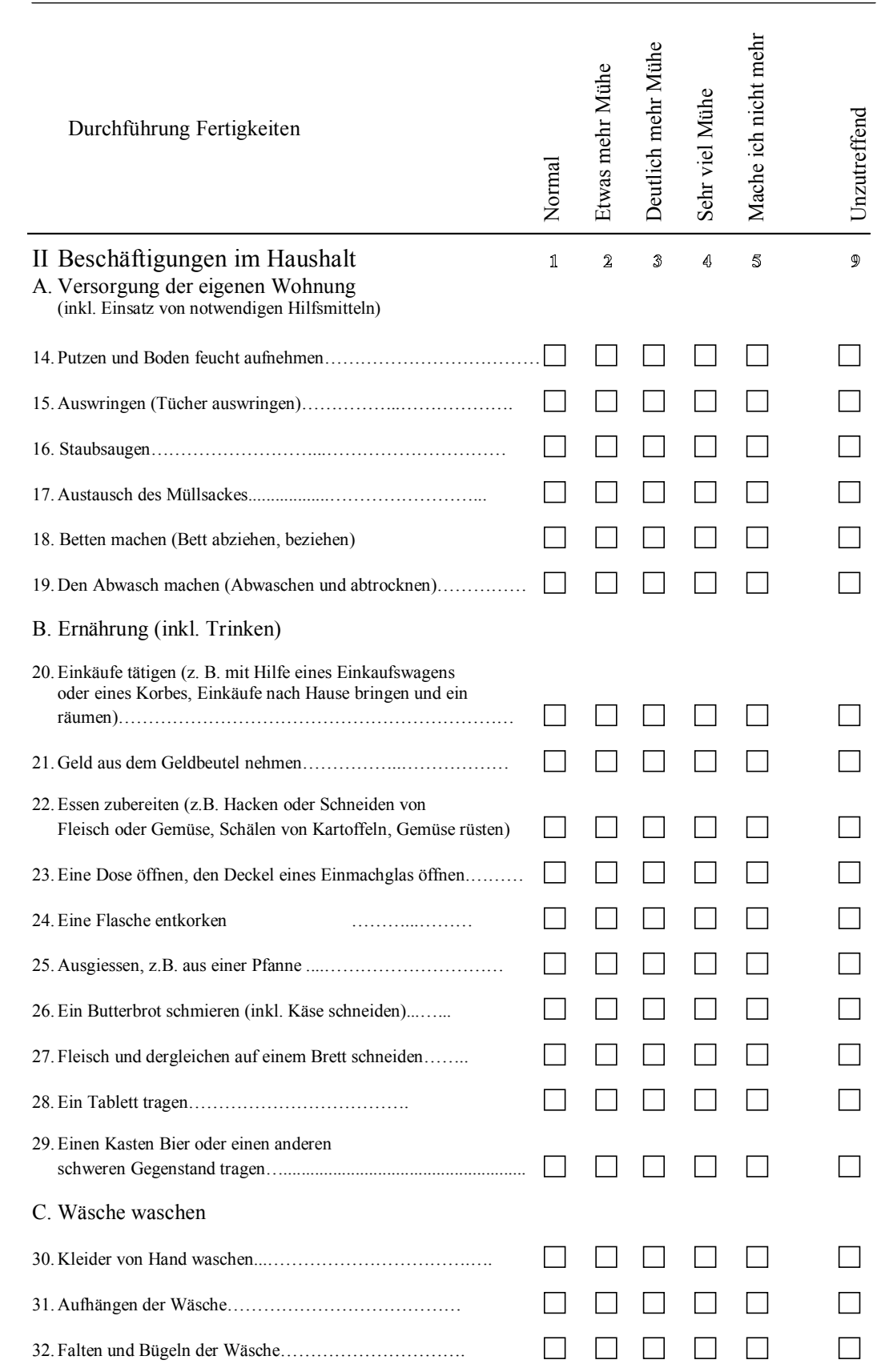




\begin{tabular}{|c|c|c|c|c|c|c|}
\hline Durchführung Fertigkeiten & $\begin{array}{l}\bar{\Xi} \\
\tilde{E} \\
\text { z }\end{array}$ & 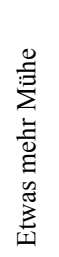 & 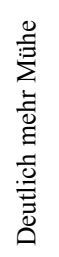 & 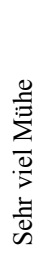 & 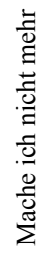 & 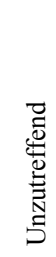 \\
\hline III Freizeitaktivitäten & 1 & 2 & 3 & 4 & 5 & (2) \\
\hline 33. Sport treiben (Einzel- oder Mannschaftsport)............. & $\square$ & $\square$ & $\square$ & $\square$ & $\square$ & $\square$ \\
\hline 34. Handarbeiten und handwerkliche Arbeit............. & $\square$ & $\square$ & $\square$ & $\square$ & $\square$ & $\square$ \\
\hline
\end{tabular}

\section{V Soziale Aktivitäten}

35. Ausflüge oder Tagestouren unternehmen.

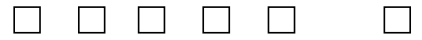

36. In den Urlaub fahren (inkl. auswärtige Übernachtung).. ......

37. Mit Kindern oder Tieren spielen.

PS: Bei Frage 35 und 36:

Bitte berücksichtigen Sie bei Ihrer Antwort auch das Reisen selbst, an- und abziehen von Kleidern und die

Möglichkeit sich den betroffenen Arm anzustossen.

Extra zu Frage 36:

Bitte berücksichtigen Sie bei Ihrer Antwort auch die damit verbundenen Tätigkeiten wie z.B.: Kofferpacken, mit dem Flugzeug reisen, Autofahren, Zelt aufstellen.

\section{Sonstiges}

38. Benutzung eines Computers oder einer Schreibmaschine (tippen)

39. Schreiben (von Hand).

40. Schneiden (mit einer Schere)

41. Mit einem Schlüssel die Haustüre öffnen inkl. gegen die Tür drücken, hochheben der Tür usw.

42. Die Fahrt zu Geschäften, zur Arbeit usw. mit dem Fahrrad..

43. Die Fahrt zu Geschäften, zur Arbeit usw. mit dem Auto...

44. Die Fahrt zu Geschäften, zur Arbeit usw. mit öffentlichen Verkehrsmitteln...

\section{Arbeit}

45. Ausübung Ihres Berufs daheim oder auswärts (ohne Haushaltsarbeiten).. 


\section{CHAPTER 6}

Translating the Dutch Walking Stairs, Walking Ability and Rising and Sitting Questionnaire into German and assess its construct validity with VAS measures of pain and activity in daily living 


\section{Abstract}

Background The Dutch Walking Stairs, Walking Ability and Rising and Sitting Questionnaire are three validated instruments to measure physical activity and limitations in daily living in patients with lower extremity disorders living at home of which no German equivalents are available.

Objective Our scope was to translate the Walking Stairs, Walking Ability and Rising and Sitting Questionnaires into German and to verify its construct validity in the two domains pain and activity in daily living by comparing them with the corresponding VAS measures.

Methods/Design We translated the Walking Stairs, Walking Ability and Rising and Sitting Questionnaire according to published guidelines. Demographic data and validity were assessed in 52 consecutive patients with Complex Regional Pain Syndrome of the lower extremity. Information on age, duration of symptoms, type of Complex Regional Pain Syndrome and type of initiating event were obtained. We assessed the construct validity in the two domains pain and activity in daily living by comparing them with the corresponding measures on the visual analogue scale.

Results We found that variability in the German Walking Stairs, Walking Ability and Rising and Sitting Questionnaires was largely explained by measures of pain and activity in daily living on the visual analogue scale.

Conclusion Our study shows that the domains pain and activity in daily living are properly represented in the German versions of the Walking Stairs, Walking Ability and Raising and Sitting Questionnaire. We would like to propagate their use in clinical practice and research alike. 


\section{Background}

Complex Regional Pain Syndrome (CRPS) is a painful condition that often results in substantial disability [1]. In the past the focus of CRPS research was mainly on symptoms and pain. Little attention has been given to the disabilities associated with CRPS. As a consequence, little information is available on the problems CRPS patients encounter in activities of daily living, and specific measurement instruments to address these problems are lacking [2].

We are only aware of one instrument, which allows measuring the functional limitation of CRPS patients. In 2000, Oerlemans et al. developed and validated the Radboud Skill Questionniare (RASQ) to map alterations in the level of disability in patients with CRPS of the upper extremity [3]. Today the RASQ is available in Dutch [3], English (not validatd yet) and German language. Various instruments are available to measure activity limitations of the lower extremity [4-9], but we are not aware of a corresponding questionnaire for patients with CRPS of the lower extremity. Most of these existing instruments do not provide a detailed measurement of activity limitation of the lower extremity perceived by the patients. Between 1996 and 2005 a Dutch group of researchers developed and validated three separate tools in Dutch assessing walking ability, including walking stairs, as well as rising and sitting [10-13]. These instruments were applied in various lower extremity disorders such as osteoarthritis, amputation, diabetic foot problems and CRPS 1. These instruments serve as disability measures in a large Dutch CRPS research consortium [14]. Up to now, these instruments are only available in Dutch and English (not validated). In this paper we describe how we translated the Walking Stairs, Walking Ability and Rising and Sitting Questionnaire into German and how we verified its construct validity in the two domains pain and activity in daily living by comparing them with the corresponding measures on the visual analogue scale (VAS).

\section{Materials and Methods}

\section{Recruitment sources and data acquisition}

We recruited patients from the outpatient clinic of Balgrist University Hospital and through ads on two self-help homepages for patients afflicted with CRPS (www.morbus-sudeck.ch, http://sudeck.foren-city.de). We included all eligible and consenting adult patients suffering from CRPS 1 or 2 of the lower extremity, which fulfilled International Association for the Study of Pain (IASP) criteria and had an illness duration of more than 3 months. The study protocol was approved by the local Ethics Committee and informed consent was obtained from all participants. 


\section{Assessment instrument}

The Walking Stairs [13], Walking Ability [12] and Rising and Sitting Questionnaire $[10,11]$ aim at determining perceived activity limitations in patients with lower extremity disorders. They are self administered questionnaires including a total of 79 dichotomous items. The scores of the specific three subdomains can be calculated as well as the total score of all three questionnaires.

\section{Translation process}

We followed a sequential forward and backward translation approach (see figure 1) [15]. Two professional translators translated the original Dutch version of the Walking Stairs, Walking Ability and Rising and Sitting Questionnaire into German. In a consensus meeting a rheumatologist, a specialist in physical medicine and rehabilitation, a physical therapist and an epidemiologist assessed the consistency of the translation and judged its face validity. They then agreed on the first German version for these formats. The questionnaire was pilot tested in 5 CRPS patients to identify difficulties in comprehension and interpretation of the questions. A Dutch translator with experience in biomedical sciences but unaware of the original versions performed a backward translation of the German version into the source language (Dutch). A team of experts (a rehabilitation specialist, a rheumatologist, an epidemiologist and a physical therapist) compared the back translation with the Dutch versions to check for conceptual discrepancies. After a second pilot test ( $n=5$ CRPS patients), the translation team discussed the comments from these patients and decided in consensus on modifications. Finally, the experts approved the final German version of all three questionnaires (see appendix A).

\section{Validation process}

All three questionnaires were offered to CRPS patients meeting the inclusion criteria. Patients received the questionnaires either during a visit in our outpatient clinic or by mail. Participants were asked to complete the questionnaires during the same day and to mail them back to our institution. In order to assess the construct validity of the questionnaires, we assessed pain and self perceived restriction in activities in daily (ADL) living on the visual analogue scale (VAS) $(0=$ no pain/restriction, $10=$ worst pain/ maximal restriction). We hypothesized, that a higher score on the VAS (pain and ADL) is associated with a more severe functional impairment in CRPS patients. 


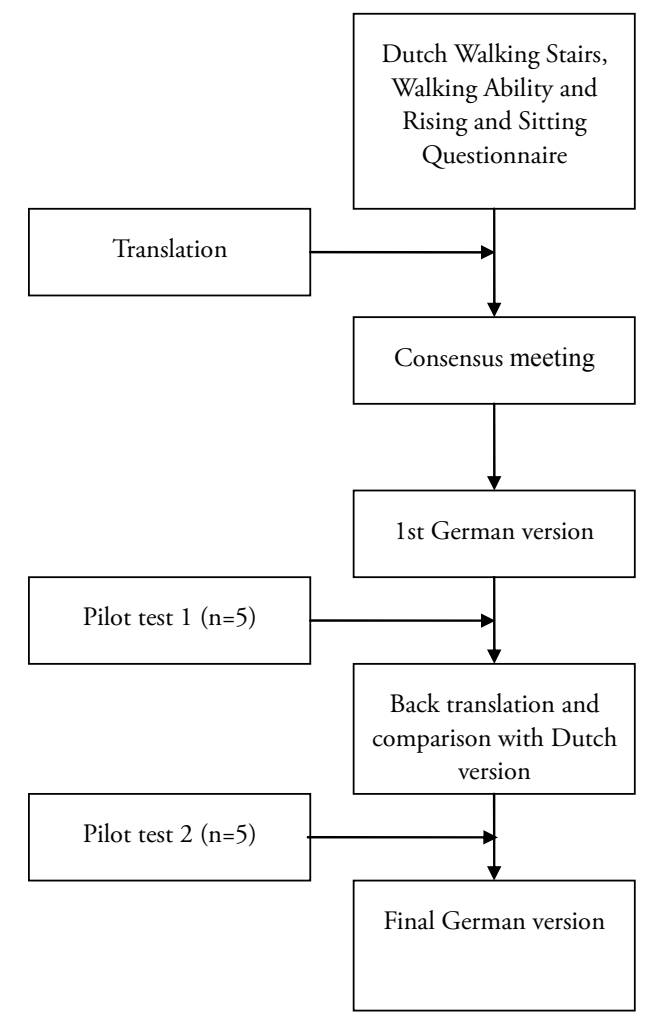

Figure 1: Flow diagram of the development process of the German Walking Stairs, Walking Ability and Rising \& Sitting questionnaire

\section{Statistical analysis}

Values are reported as mean $\pm \mathrm{SD}$, medians and interquartile ranges (where appropriate) or as absolute number and percentage. Linear regression analysis and mean prediction interval were used to assess the relationship between the three questionnaires and the VAS pain respectively VAS of activities of daily living. A probability value of $p<0.05$ was considered statistically significant for all tests. We performed all statistical analyses with the SPSS 12 statistical software package. (SPSS Inc. Headquarters, 233 S. Wacker Drive, 11th floor Chicago, Illinois 60606). 


\section{Results}

Translation and instrument development

The wording of the questions and response options correspond to the original version. We did not add or remove items nor did we change response options.

Demographic and clinical characteristics

The demographic and clinical characteristics of the participants are shown in table 1. We enrolled 52 patients suffering from CRPS of the lower extremity (females/males: 46/6). Forty patients (76.9\%) suffered from CRPS of the foot and 11 (21.2\%) from the knee. Trauma (48.1\%) and surgery (46.2\%) were the most common initiating events. Median disease duration was 2.2 years (IQR 0.79 to 5.19).

Table 1: Demographic and clinical characteristics of study population $(\mathrm{N}=52)$

\begin{tabular}{|c|c|}
\hline \multicolumn{2}{|l|}{ Gender } \\
\hline Male & $6(11.5 \%)$ \\
\hline Female & $46(88.5 \%)$ \\
\hline Mean age ( \pm standard deviation) & $50.3 \pm 14.5$ years \\
\hline Age range & 18.2-76.7 years \\
\hline CRPS* 1 & $50(96.2 \%)$ \\
\hline CRPS* 2 & $2(3.8 \%)$ \\
\hline \multicolumn{2}{|l|}{ Affected body part } \\
\hline Foot & $40(76.9 \%)$ \\
\hline Knee & $11(21.2 \%)$ \\
\hline Other & $1(1.9 \%)$ \\
\hline Median (interquartile range) of number of years with CRPS* & 2.2 years $(0.79-5.19)$ \\
\hline \multicolumn{2}{|l|}{ Initiating event } \\
\hline Trauma & 25 (48.1\%) \\
\hline Surgery & $24(46.2 \%)$ \\
\hline Other & $3(5.8 \%)$ \\
\hline
\end{tabular}

* CRPS: Complex regional pain syndrome

Descriptive statistic of pain and activity limitation on visual analogue scale and the Walking Stairs, Walking Ability and Rising and Sitting Questionnaire

Self perceived pain and restrictions in activities in daily living were $5.7+2.1$ respectively $5.6+2.2$ on the VAS, respectively. Average of the total score of the questionnaires was $29.4+13.2$ (walking stairs $5.6+2.5$, walking ability $11.9+5.6$, rising and sitting 11.9+6.5). For the detailed analysis see table 2. 
Table 2: Descriptive statistic of pain and activity limitation on visual analogue scale, and the Walking Stairs, Walking Ability and Rising and Sitting Questionnaire $(\mathrm{N}=52)$

\begin{tabular}{lc}
\hline & Score $( \pm$ SD) \\
\hline Pain (VAS) & $5.7 \pm 2.1$ \\
Restrictions in activities of daily living (VAS) $^{a}$ & $5.6 \pm 2.2$ \\
Total score questionnaires & $29.4 \pm 13.2$ \\
$\quad$ Walking stairs & $5.6 \pm 2.5$ \\
$\quad$ Walking ability & $11.9 \pm 5.6$ \\
$\quad$ Rising and sitting & $11.9 \pm 6.5$
\end{tabular}

a VAS: Visual analogue scale $(0=$ no pain, no restriction, $10=$ worst pain, maximal restriction)

Construct validity for pain

VAS pain scores explained a considerable amount of variability of the total score $\left(R^{2}=0.28\right)$. Higher VAS pain scores indicated higher total functional limitation (coefficient or slope $=3.33(95 \% \mathrm{Cl} 1.82$ to $4.84 ; \mathrm{p}<0.001)$ ). These results were consistent within the subdomains walking stairs (slope $=0.59(95 \% \mathrm{Cl} 0.30$ to $0.88 ; p<0.001)$ ), walking ability (slope $=1.49(95 \% 0.85$ to $2.21 ; p<0.001)$ ), and raising and sitting (slope $=1.25(95 \% \mathrm{Cl} 0.45$ to $2.06 ; \mathrm{p}=0.003)$ ). For details see Table 3 and Figure 2.

Table 3: Construct validity compared with VAS pain $(\mathrm{N}=52)$

\begin{tabular}{lllll}
\hline Domain & Slope * & $95 \% \mathrm{Cl}$ & $\mathrm{p}$-Value & \multicolumn{1}{l}{$\mathbf{R}^{\mathbf{2}}$} \\
\hline Walking stairs & 0.59 & $0.30-0.88$ & $<0.001$ & 0.25 \\
Walking ability & 1.49 & $0.85-2.12$ & $<0.001$ & 0.31 \\
Rising and sitting & 1.25 & $0.45-2.06$ & 0.003 & 0.17 \\
Total score & & & & \\
\hline
\end{tabular}

* indicating strength of association between VAS Scores and questionnaire domains. (From regression analysis) 

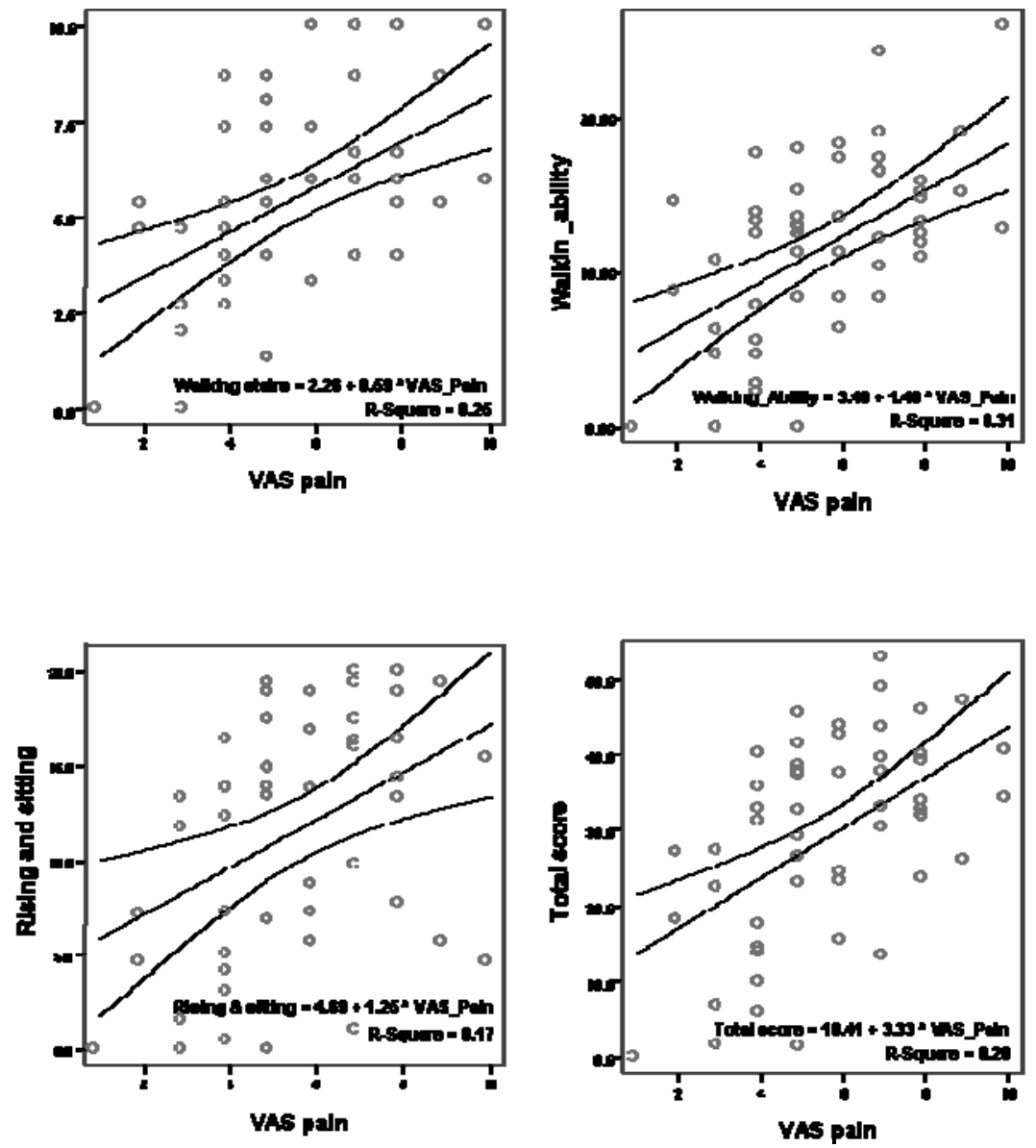

Figure 2: Linear regression lines with 95\% prediction intervals for means (pain)

Construct validity for activities in daily living

VAS ADL scores explained a substantial amount of variability of the total score $\left(\mathrm{R}^{2}\right.$ $=0.37$ ). Higher VAS ADL scores indicated higher total functional limitation (slope $=8.77(95 \% \mathrm{Cl} 2.32$ to 5.04; $<<0.001))$. These results were consistent across the subdomains walking stairs (slope $=1.43(95 \% \mathrm{Cl} 0.51$ to $0.99 ; \mathrm{p}<0.001)$ ), walking ability (slope $=2.61(95 \% \mathrm{Cl} 1.10$ to $2.23 ; \mathrm{p}=<0.001)$ ) and raising and sitting (slope $=4.47(95 \% \mathrm{Cl} 0.50$ to $2.03 ; \mathrm{p}<0.02)$ ). For details see Table 4 and Figure 2. 
Table 4: Construct validity compared with VAS ADL $(\mathrm{N}=52)$

\begin{tabular}{lllll}
\hline Domain & Slope * & 95\%Cl & p-Value & $\mathbf{R}^{2}$ \\
\hline Walking stairs & 1.43 & $0.51-0.99$ & $<0.001$ & 0.43 \\
Walking ability & 2.61 & $1.10-2.23$ & $<0.001$ & 0.41 \\
Rising and sitting & 4.74 & $0.50-2.03$ & 0.002 & 0.18 \\
& & & & \\
Total score & 8.77 & $2.32-5.04$ & $<0.001$ & 0.37 \\
\hline
\end{tabular}

* indicating strength of association between VAS Scores and questionnaire domains. (From regression analysis)
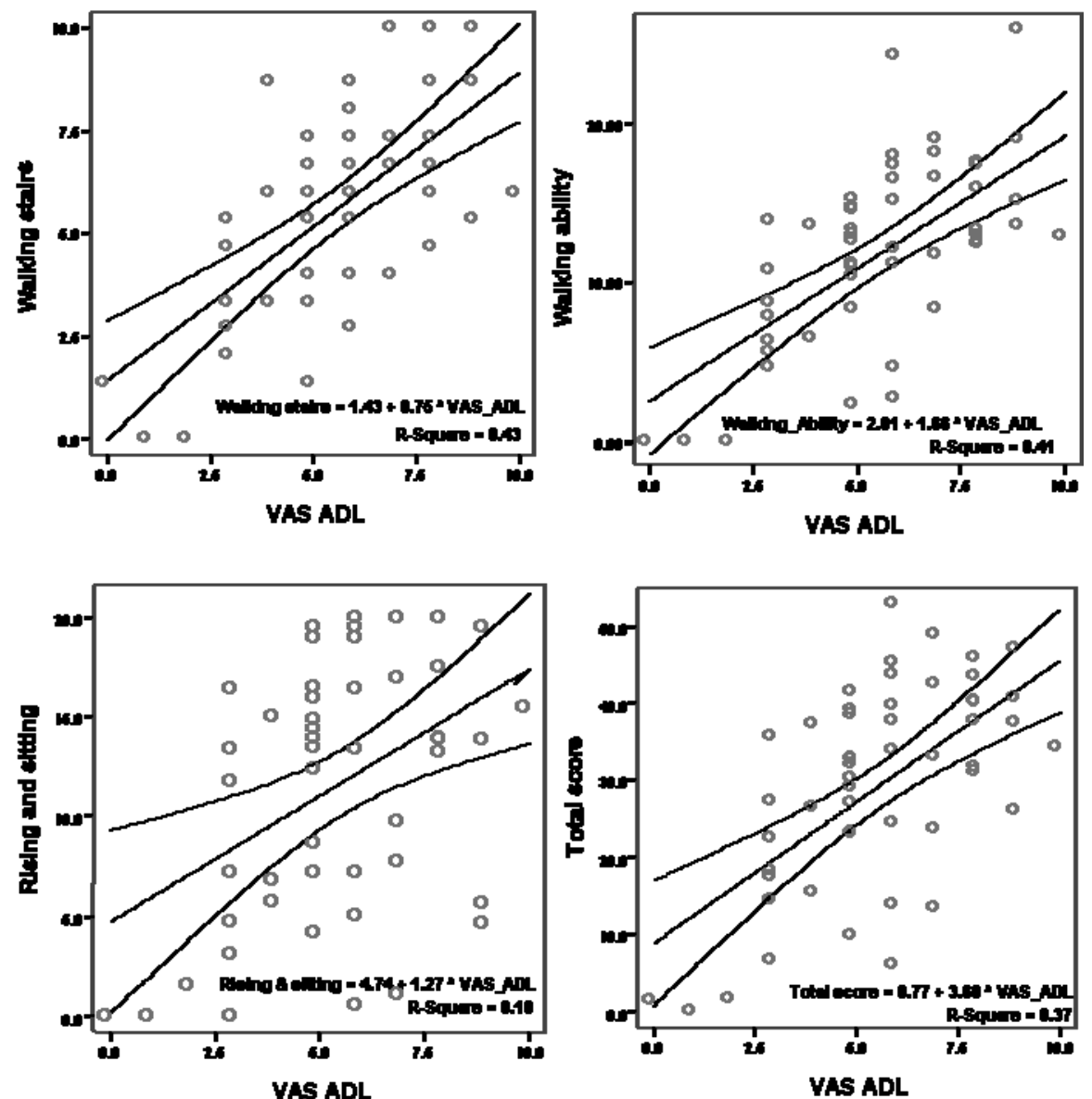

Figure 3: Figure 2: Linear regression lines with 95\% prediction intervals for means (ADL)

\section{Discussion}

We successfully translated the Walking Stairs, Walking Ability and Rising \& Sitting questionnaire into German. Assessing its construct validity we found that the German instrument adequately represents activity limitations in daily living and pain in 
patients with CRPS of the lower extremity. Score values were positively correlated with VAS values for pain and activity in daily living. However, the correlation of the total score of the three questionnaires was better with VAS ADL than VAS pain. We hypothesize that this difference can be explained by the fact, that pain is a different construct than activity [16].

The translation process itself had no issues of concern, all forward and backward translations were consistent with each other and with the original version. We followed the rigorous translation method proposed by Wild et al. [17], which consisted of a forward and backward translation by professional translators, and by a consensus meeting between researchers. By applying this robust methodology we ensured that the content, integrity and essence of the questionnaire items are maintained and expressed clearly and accurately from one language to another.

To our knowledge, this is the first German translation and external validation of the original Dutch version of the Walking Stairs, Walking Ability and Rising \& Sitting Questionnaire allowing the standardized measurement of activity limitations of patients suffering from CRPS of the lower extremity. Another strength is the methods we applied to derive the translated version of the three questionnaires. Our study also has some limitations. First, since diagnosis of CRPS is still a matter of debate our sample might not be representative for a larger CRPS population. The diagnosis of CRPS is based on clinical findings (including sensory, autonomic, motor and trophic changes) and the fulfilment of established diagnostic criteria [18]. We only included patients fulfilling the criteria established by the International Association for the Study of Pain (IASP) [19] in all participants. However, these IASP criteria have been criticized because they are symptom based and show a low specificity [1]. Second, unlike the upper extremities, an instrument for lower extremities was not available to assess the criterion validity of the three questionnaires. Therefore we had to validate them by assessing the construct validity in respect of self reported activity limitations in daily living and pain. Arguably this limits the quality of this study.

This validated German version will help to determine the disability of patients suffering from CRPS of the lower extremity in German speaking countries in clinical practice as well as in research. This is important, if this questionnaire will be used to document follow up in longitudinal studies or intervention studies [14, 22]. In addition, it allows a comparison of the results of studies from different origins. In particular, the German versions of the German Walking Stairs, Walking Ability and Rising and Sitting Questionnaires allow us now to collect data for the Swiss CRPS cohort study [22] and to compare the results with our Dutch collaborators within the TREND consortium.

Investigators in German-speaking countries now have the possibility to assess physical activity and limitations in daily living in patients with CRPS of the lower extremity.

Information about patients' disability can be used to enhance clinical decision making and to observe the course of the condition. 
Our study shows that the domains pain and activity in daily living are properly represented in the German versions of the Walking Stairs, Walking Ability and Raising and Sitting Questionnaire. We would like to propagate their use in clinical practice and research alike. 


\section{References}

1. Bruehl S, Harden RN, Galer BS, Saltz S, Bertram M, Backonja M, et al. External validation of IASP diagnostic criteria for Complex Regional Pain Syndrome and proposed research diagnostic criteria. International Association for the Study of Pain. Pain 1999; 81(1-2): 147-54.

2. Perez RS, Roorda LD, Zuurmond WW, Bannink, II, Vranken JH, de Lange JJ. Measuring perceived activity limitations in lower extremity Complex Regional Pain Syndrome type 1 (CRPS I): test-retest reliability of two questionnaires. Clin Rehabil 2002; 16(4): 454-60.

3. Oerlemans HM, Cup EH, DeBoo T, Goris RJ, Oostendorp RA. The Radboud skills questionnaire: construction and reliability in patients with reflex sympathetic dystrophy of one upper extremity. Disabil Rehabil 2000; 22(5): 233-45.

4. Mahoney FI, Barthel DW. Functional Evaluation: The Barthel Index. Md State Med J 1965; 14: 615.

5. Keith RA, Granger CV, Hamilton BB, Sherwin FS. The functional independence measure: a new tool for rehabilitation. Adv Clin Rehabil 1987; 1: 6-18.

6. Ware JE, Jr., Sherbourne CD. The MOS 36-item short-form health survey (SF-36). I. Conceptual framework and item selection. Med Care 1992; 30(6): 473-83.

7. Fries JF, Spitz PW, Young DY. The dimensions of health outcomes: the health assessment questionnaire, disability and pain scales. J Rheumatol 1982; 9(5): 789-93.

8. Bellamy N, Buchanan WW, Goldsmith $\mathrm{CH}$, Campbell J, Stitt LW. Validation study of WOMAC: a health status instrument for measuring clinically important patient relevant outcomes to antirheumatic drug therapy in patients with osteoarthritis of the hip or knee. J Rheumatol 1988; 15(12): 1833-40.

9. Meenan RF, Mason JH, Anderson JJ, Guccione AA, Kazis LE. AIMS2. The content and properties of a revised and expanded Arthritis Impact Measurement Scales Health Status Questionnaire. Arthritis Rheum 1992; 35(1): 1-10.

10. Roorda LD, Molenaar IW, Lankhorst GJ, Bouter LM. Improvement of a questionnaire measuring activity limitations in rising and sitting down in patients with lower-extremity disorders living at home. Arch Phys Med Rehabil 2005; 86(11): 2204-10.

11. Roorda LD, Roebroeck ME, Lankhorst GJ, Tilburg TV. The walking ability questionnaire: hierarchical scales to measure disabilities in rising and walking. Revalidata 1996; 18: 34-38.

12. Roorda LD, Roebroeck ME, van Tilburg T, Molenaar IW, Lankhorst GJ, Bouter LM, et al. Measuring activity limitations in walking: development of a hierarchical scale for patients with lower-extremity disorders who live at home. Arch Phys Med Rehabil 2005; 86(12): 2277-83.

13. Roorda LD, Roebroeck ME, van Tilburg T, Lankhorst GJ, Bouter LM. Measuring activity limitations in climbing stairs: development of a hierarchical scale for patients with lower-extremity disorders living at home. Arch Phys Med Rehabil 2004; 85(6): 967-71.

14. Perez RS, Van Hilten JJ, Marinus J, TREND: Source document 1 - Study designs and outcomes (Version 5). 2007.

15. Bullinger M. Creating and evaluation cross-cultural instruments. In: Spilker B, Editor. Quality of life and pharmacoeconomics in clinical trials. Philadelphia: Lippincot; 1996, p. 659-68.

16. WHO. ICIDH: International Classification of Impairments, Disabilities and Handicaps. In: WHO, editors. Geneva; 1980.

17. Wild D, Grove A, Martin M, Eremenco S, McElroy S, Verjee-Lorenz A, Erikson P. Principles of Good Practice for the Translation and Cultural Adaptation Process for Patient-Reported Outcomes (PRO) Measures: report of the ISPOR Task Force for Translation and Cultural Adaptation. Value Health 2005; 8(2): 94-104.

18. Harden R, Bruehl S. Diagnostic criteria: The statistical derivation of the four criterion factors. In: Wilson P, Stanton-Hicks M, RN Harden R, editors. CRPS: Current Diagnosis and Therapy. Seattle, WA: IASP Press; 2005, p. 45-58. 
19. Merskey H, Bogduk N. Classification of chronic pain: description of chronic pain syndrome and definitions of pain terms. In: editors. Seattle: IASP Press; 1994.

20. Schasfoort FC, Bussmann JB, Stam HJ. Correlation between a novel upper limb activity monitor and four other instruments to determine functioning in upper limb complex regional pain syndrome type I. J Rehabil Med 2005; 37(2): 108-14.

21. Hoeymans N, Feskens EJ, van den Bos GA, Kromhout D. Measuring functional status: crosssectional and longitudinal associations between performance and self-report (Zutphen Elderly Study 1990-1993). J Clin Epidemiol 1996; 49(10): 1103-10.

22. Brunner F, Bachmann LM, Weber U, Kessels AG, Perez RS, Marinus J, Kissling R. Complex regional pain syndrome 1--the Swiss cohort study. BMC Musculoskelet Disord 2008; 9: 92. 



\section{CHAPTER 7}

Bisphosphonates for the therapy of Complex Regional Pain Syndrome 1 Systematic review 


\section{Abstract}

Objectives Serveral studies found that bisphosphonates counteract locally increased bone resorption and associated pain in patients with Complex Regional Pain Syndrome 1 (CRPS 1). We performed a systematic review of all randomised controlled trials to assess the benefit of bisphosphonates in the treatment of CRPS I patients with bone loss.

Data sources We searched Medline, Embase (April 2007) and the Cochrane Library and screened bibliographies of included studies.

Review methods We selected randomised trials comparing bisphosphonates with placebo, with the goal of improving pain, function and quality of life in patients with CRPS 1 . Two reviewers independently assessed trial eligibility and quality, and extracted data. Where data were incomplete or unclear, conflicts were resolved with discussion and/or trial authors were contacted for further details. We calculated the study size weighted pooled mean reduction of pain intensity (measured with a visual analogue scale (VAS)).

Results Four trials of moderate quality fulfilled our inclusion criteria. In respect to function and quality of life there was a trend in favour of bisphosphonates but differences in outcome assessment impeded pooling of results. Two trials provided sufficient data to pool pain outcomes. Bisphosphonates reduced pain intensity by 22.4 and $21.6 \mathrm{~mm}$ on a VAS after 4 and 12 weeks of follow-up. Data on adverse effects were scarce.

Conclusions The very limited data reviewed showed that bisphosphonates have the potential to reduce pain associated with bone loss in patients with CRPS 1 . However, at present there is not sufficient evidence to recommend their use in practice. 


\section{Introduction}

Complex Regional Pain Syndrome 1 (CRPS 1) is a common, disabling and poorly understood disorder [1]. The syndrome is characterized by pain and various combinations of autonomic, sensory, motor, and trophic changes [2-4]. The precise causes of CRPS 1 are unknown; it often develops after a trauma, such as an injury or surgery [5].

Due to the complexity of this disorder, involving the peripheral as well as the central neural system, there is no evidence of an effective treatment [5]. No definite treatment algorithm has been established, although numerous therapeutic approaches have been described in the past with varying success [6]. According to the currently available guidelines, treatment is usually based on a multimodal concept including medical treatment, physical therapy, occupational therapy and psychotherapy [7-10].

Among other physical agents, the use of bisphosphonates in the treatment of CRPS 1 was recommended when calcitonin is inefficient or when calcitonin injections are not well tolerated [11]. Bisphosphonates are potent antiosteoclastic agents which are often used for the treatment of several bone related pathologies such as Paget's disease, metastatic cancer, myeloma and acute vertebral fractures.

CRPS 1 may be associated with a localized bone resorption in the affected limb, which results from osteoclastic hyperactivity [12]. Therefore, several authors hypothesized that the use of bisphosphonates might be beneficial in the treatment of CRPS 1 because these agents counteract bone resorption and show some analgetic effect. (Reviewed in [13]) We set out to perform a systematic review of all randomized controlled trials testing the benefit of bisphosphonates in CRPS 1 treatment and to summarize the value of this promising drug.

\section{Methods}

This systematic review was performed applying rigorous published methods (Center for Reviews and Dissemination, Report 4, 2001).

\section{Identification of studies}

We searched Medline (PubMed Version) and Embase (Ovid ${ }^{\circledR}$ interface) from inception to April 2007 using the search terms Complex regional pain syndrome, CRPS, algoneurodystrophy, algodystrophy, shoulder-hand syndrome, reflex sympathetic dystrophy, RSD, and Sudeck. Searches in the Cochrane Central Register of Controlled Trials (2007, Issue 2) and screening bibliographies of all included studies complemented our searches. We imposed no language restrictions. We looked for 
randomised trials comparing bisphosphonates with placebo, with the goal of improving pain, function and quality of life in patients with CRPS 1.

\section{Study selection}

One reviewer (FB) designed the search strategy and performed the searches. Two reviewers (FB and AS) independently screened the titles, keywords and abstracts of all retrieved records against the inclusion criteria. They looked for randomised studies including patients with the diagnosis of CRPS 1 and comparing bisphosphonates against placebo. Then, the reviewers assessed the full text of potentially eligible papers to ascertain that the studies met the inclusion criteria. Disagreements on inclusion were resolved by discussion or through arbitration by a third reviewer $(\mathrm{LMB})$.

\section{Data extraction}

Two reviewers (FB, AS) independently extracted the salient features from each trial using a data extraction form that was pretested using one included trial. From each study we secured setting (e.g. year, country of origin), number of participants, and site of CRPS, type of intervention, dosage and application mode and duration of intervention. We also registered types of outcome measures, timing of outcome assessments and the corresponding results. Finally, we registered all published adverse effects.

\section{Assessment of study quality}

Two reviewers (FB, AS) independently evaluated the methodological quality of each included trial. Based on existing recommendations [14] we developed a quality assessment form. The form was piloted on the first paper to check for any misunderstandings when addressing the items and revised where necessary (see Appendix 1). Disagreements were resolved by consensus. A third reviewer (LMB) arbitrated persisting disagreements.

\section{Statistical analysis}

In this study we assessed the agreement according to published recommendations between two reviewers using kappa statistics.[15] The kappa statistics is based on comparing the observed proportion of agreement between two readings $\left(A_{\text {obs }}\right)$ made by the two testers, with the proportion of agreements that would be expected simply by chance $\left(A_{\text {exp }}\right)$.

Kappa $=\left(A_{\text {obs }}-A_{\text {exp }}\right) /\left(1-A_{\text {exp }}\right)$

Landis and Koch propose the following interpretation of the kappa statistic: kappa $>0.75$ represents excellent agreement, values of kappa between 0.4 and 0.75 represent fair to good agreement, and kappa values less than 0.4 show moderate or poor agreement [16]. Where available, we calculated differences in outcome 
parameters from baseline per group and analysed differences between groups. We decided to pool the results of studies if they reported on the same outcome measure and timing. These data were only available for pain assessment using a visual analogue scale at four and twelve weeks of follow-up. Mean VAS differences were pooled using variance weights.

\section{Results}

Our searches retrieved 1767 records from which 16 appeared to be potentially relevant. Full text assessment resulted in exclusion of 12 additional studies. In total four trials were included in this review [12, 17-19]. (For study selection details please see figure 1 ).

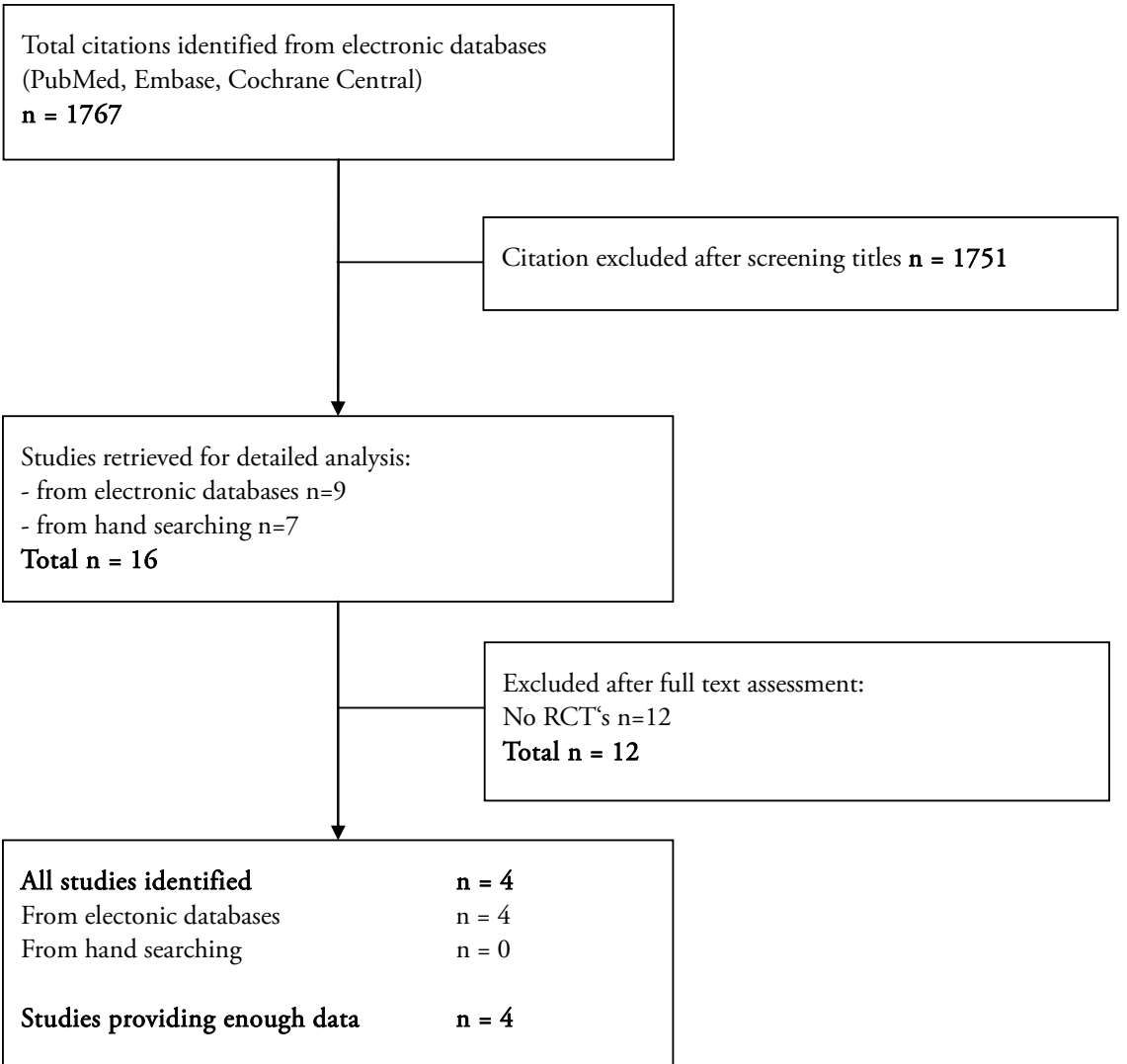

Fig. 1: Study flow from identification to final inclusion of studies 
Description of studies

In total 118 patients (intervention group $n=59$, control group $n=59$ ) with CRPS 1 were treated. All four RCT's were small, including less than 30 patients in one study arm. Mean age was 51.7 years; mean disease duration was 12.5 months (range 3.5-21.6 months). The site of CRPS 1 was more in the lower extremity $(n=89)$ than in the upper extremity $(n=30)$. Trauma $(n=38)$ and fracture $(n=28)$ were the most frequent initiating events causing CRPS 1 . The participants were treated either with oral $(n=1)$ [17] or intravenous administration $(n=3)[12,18$, 19] of a biphosphonate compound. Alendronate was used in two studies, pamidronate [18] and clondronate [19] were administered once. Side effects were evaluated in all 4 studies and were rare.

The characteristics of the included trials are summarized in Table 1. 


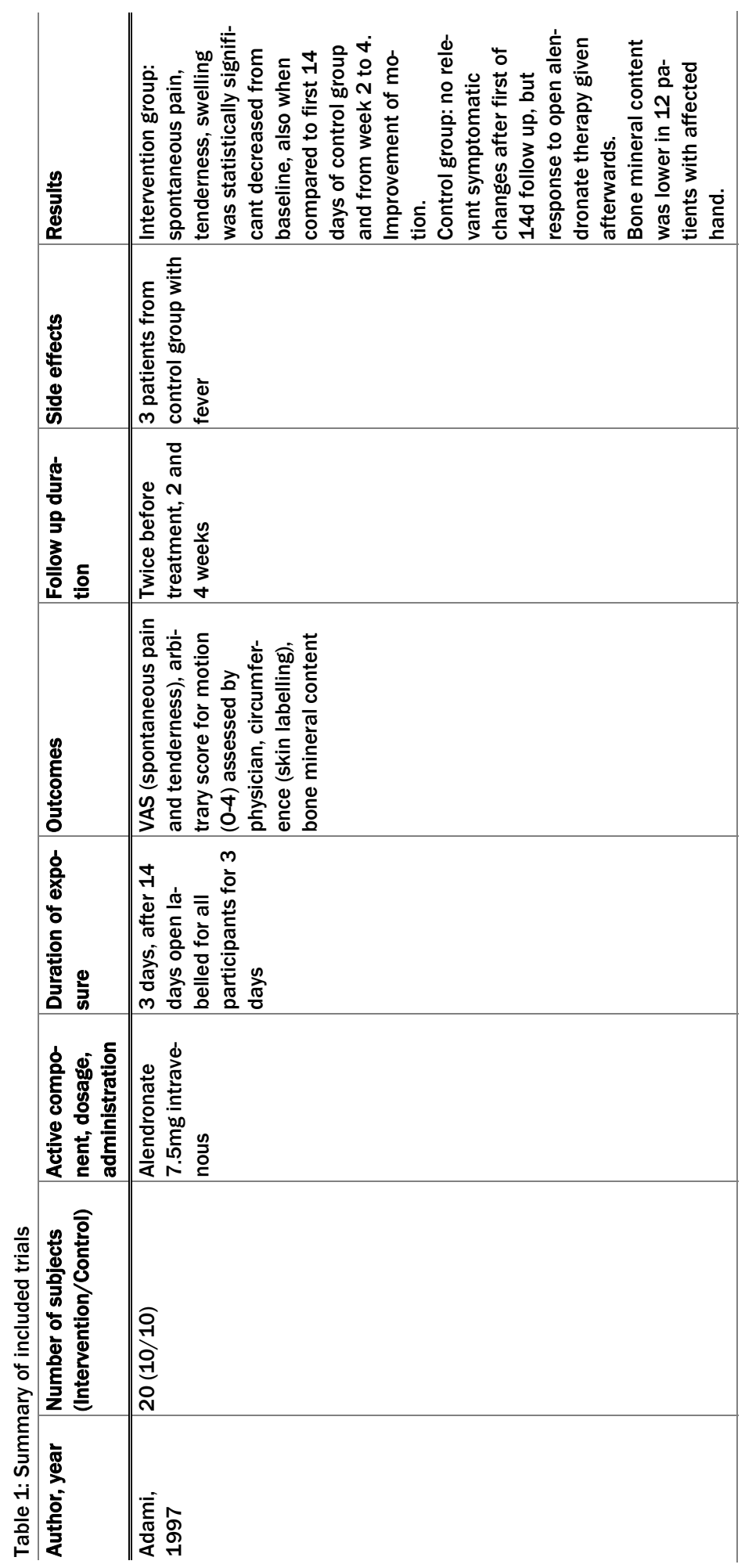




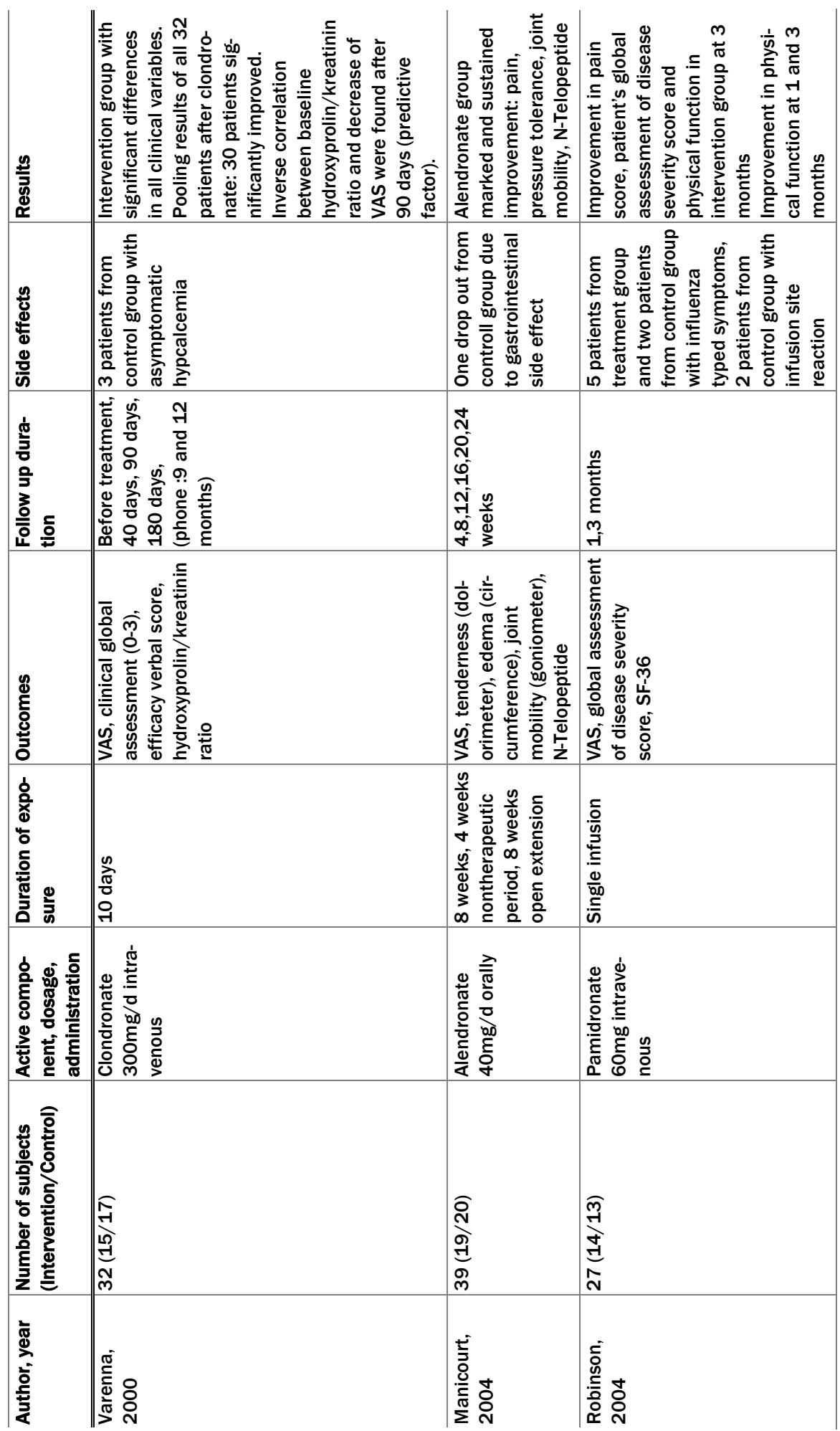




\section{Methodological quality of included studies}

The agreement between the two reviewers was excellent. (Agreement on 78 of the 88 item scores (89\%); kappa $=0.80)$. No arbitration was necessary.

All 4 included studies were considered to be of moderate quality (Table 2).

Table 2: Methodological quality assessment of included studies

\begin{tabular}{|c|c|c|c|c|}
\hline \multicolumn{5}{|l|}{ Descriptors } \\
\hline Author/Year: & $\begin{array}{c}\text { Adami } \\
1997\end{array}$ & $\begin{array}{c}\text { Varenna } \\
2000\end{array}$ & $\begin{array}{l}\text { Manicourt } \\
2004\end{array}$ & $\begin{array}{l}\text { Robinson } \\
2004\end{array}$ \\
\hline \multicolumn{5}{|l|}{ External Validity } \\
\hline Population & 1 & 1 & 1 & 1 \\
\hline Intervention(s) & 1 & 1 & 1 & 1 \\
\hline Outcomes & 1 & 1 & 1 & 1 \\
\hline Duration of follow-up & 1 & 1 & 1 & 1 \\
\hline Assessment of adverse effects & 1 & 1 & 1 & 1 \\
\hline \multicolumn{5}{|l|}{ Internal Validity } \\
\hline Selection of a prognostically homogenous study population & 2 & 3 & 1 & 3 \\
\hline Blinding of persons who assess inclusion criteria & 2 & 4 & 4 & 4 \\
\hline $\begin{array}{l}\text { Pre-stratification on prognostically relevant } \\
\text { variables }\end{array}$ & 4 & 4 & 4 & 3 \\
\hline Random allocation (description of procedure) & 2 & 1 & 1 & 2 \\
\hline Registration of loss to follow-up & 1 & 1 & 1 & 1 \\
\hline Blinding of patients & 1 & 1 & 1 & 1 \\
\hline Blinding of persons(s) who implement interventions & 1 & 1 & 4 & 1 \\
\hline $\begin{array}{l}\text { Registration of co-interventions that bear on } \\
\text { outcome for each group }\end{array}$ & 2 & 1 & 3 & 3 \\
\hline Blinding of persons(s) who assess treatment effects & 4 & 1 & 4 & 4 \\
\hline Check to what extent blinding was successful & 2 & 2 & 4 & 2 \\
\hline \multicolumn{5}{|l|}{ Data description and analysis } \\
\hline $\begin{array}{l}\text { Measures of central tendency and their confidence inter- } \\
\text { vals }\end{array}$ & 1 & 1 & 1 & 1 \\
\hline Statistical methods & 1 & 1 & 1 & 1 \\
\hline The way missing values were dealt with & 2 & 3 & 3 & 1 \\
\hline An intention to treat analysis & 2 & 2 & 2 & 1 \\
\hline The distributions of baseline characteristics & 3 & 1 & 1 & 1 \\
\hline $\begin{array}{l}\text { The way any unbalance in prognostic variables } \\
\text { was adjusted for(if deemed necessary) }\end{array}$ & 2 & 1 & 2 & 1 \\
\hline \multicolumn{5}{|l|}{ Compliance } \\
\hline Compliance (dose, timing) & 1 & 1 & 1 & 1 \\
\hline
\end{tabular}

1: appropriately addressed, 2: partially addressed, 3: inappropriately addressed, 4 not addressed 
Evidence of improvement of quality of life and function

Two studies showed a significant improvement of joint mobility [20, 21]. Due to different measures of range of motion, statistical pooling was not possible (goniometer [21] vs. arbitrary score [20]. One study showed a significant improvement of physical function in the treatment group by assessing SF-36 after 1 and 3 months [22]. None of the studies considered measuring the aspect of quality of life.

\section{Evidence of effectiveness}

Due to the variability in respect to interventions, enrolment criteria, control treatments, duration of follow-up visits and outcome measures, only two out of four studies were considered clinically comparable regarding pain intensity (VAS) after 4 and 12 weeks $[17,18]$. Statistical pooling showed a weighted average of -22.4 after 4 weeks and -21.6 after 12 weeks on a scale of 100 .

\section{Discussion}

This review has two findings. Evidence from trials investigating the effects of bisphosphonates in CRPS 1 are still scarce. Pooled analysis of two small trials suggests that these agents have a favourable effect on pain management. In respect to other clinically relevant outcomes four studies show trends towards favourable effects but differences in trial design impede exhaustive quantitative assessments at this stage.

In a narrative review published in 2005 in French, Chauvineau and colleagues [11] made a first attempt to summarize the effects of bisphosphonates in CRPS 1 treatment. In that review, which did not include a formal meta analysis, the authors felt that current evidence was insufficient to set proper indication for treatment or to estimate treatment effects [11]. The review did not apply up to date systematic review methodology, did not search all relevant electronic databases and was incomplete in respect to quality assessment. Since electronic searches were limited to 2003 they missed two studies $[17,18]$ out of which one study contributed data to our meta-analysis [17]. On the other hand, Chauvineau and colleagues included two studies that we excluded from our analysis. The paper by Liens et al. [23] studied patients with questionable cases of CRPS 1 and the paper by Cohen and Uebelhart [24] used an active control (calcitonin).

The strength of this study includes the application of robust systematic review methodology. We made strenuous efforts to minimize the risk of selection bias. Relevant reports were searched systematically and without language restriction. Also, we attempted to perform a meta-analysis. But, due to the limited number of available studies, the variability in terms of study population, interventions, dura- 
tion of follow-up and outcome measures, pooling of results was limited to pain intensity (VAS) after 4 and 12 weeks. Other clinically relevant outcomes such as improvements in range of motion, edema and quality of life could not be assessed meta-analytically. In addition, all studies were rather small resulting in imprecise estimates.

The current guideline published by a consensus report in 1998 does not recommend bisphosphonates in CRPS 1 treatment. Stanton-Hicks et al. only recommend the use of subcutaneous calcitonin for a mild effect on spontaneous pain, the use of oral or intravenous bisphosphonates was not part of their recommendations [8]. We think, that it is still too early to recommend broad application of bisphosphonates in CRPS 1 management. Treatment should be initiated only within research protocols that clearly define exposures, and involve standardised outcome assessments. Moreover, treatment regimens should always be based on a multidisciplinary approach rather than the use of a single medication.

In conclusion, the very limited data reviewed showed that bisphosphonates have the potential to reduce pain in patients with CRPS 1. However, at present there is not sufficient evidence to recommend their use in practice. To prove the possible beneficial effect in reducing pain, we recommend high quality randomised studies with clear inclusion and exclusion criteria and with a sufficient sample size. The outcome measures should include overall improvement in function and decreasing pain, quality of health status, return to work and side effect. In addition, optimum dosage, frequency and duration of treatment must be further examined. 


\section{References}

1. Kock FX, Borisch N, Koester B, Grifka J: Complex regional pain syndrome type I (CRPS I). Pathophysiology, diagnostics, and therapy. Orthopade 2003, 32(5):418-431.

2. Merskey $\mathrm{H}$, Bogduk $\mathrm{K}$ : Classification of chronic pain: definitions of chronic pain syndromes and definition of pain terms. Seattle: IASP Press; 1994.

3. Veldman PH, Reynen HM, Arntz IE, Goris RJ: Signs and symptoms of reflex sympathetic dystrophy: prospective study of 829 patients. Lancet 1993, 342(8878):1012-1016.

4. Bruehl S, Harden RN, Galer BS, Saltz S, Bertram M, Backonja M, Gayles R, Rudin N, Bhugra MK, Stanton-Hicks M: External validation of IASP diagnostic criteria for Complex Regional Pain Syndrome and proposed research diagnostic criteria. International Association for the Study of Pain. Pain 1999, 81(1-2):147-154.

5. Maihofner $\mathrm{C}$, Birklein F: Complex regional pain syndromes: new aspects on pathophysiology and therapy. Fortschr Neurol Psychiatr 2007, 75(6):331-342.

6. Forouzanfar T, Koke AJ, van Kleef M, Weber WE: Treatment of complex regional pain syndrome type I. Eur J Pain 2002, 6(2):105-122.

7. Stanton-Hicks MD, Burton AW, Bruehl SP, Carr DB, Harden RN, Hassenbusch SJ, Lubenow TR, Oakley JC, Racz GB, Raj PP et al: An updated interdisciplinary clinical pathway for CRPS: report of an expert panel. Pain Pract 2002, 2(1):1-16.

8. Stanton-Hicks M, Baron R, Boas R, Gordh T, Harden N, Hendler N, Koltzenburg M, Raj P, Wilder R: Complex Regional Pain Syndromes: guidelines for therapy. Clin J Pain 1998, 14(2):155-166.

9. Harden N (ed.): Complex regional pain syndrome: treatment guidelines. Milford, CT: RSDSA Press; 2006.

10. Geertzen JHB, Perez RSGM, Dijkstra PU, Kemler MA, Rosenbrand CJGM: Complex regional pain syndrome 1 guidelines. In. Edited by Specialists NSoR, Anaesthesiologists NSo. Alphen an den Rjin: Van Zuiden Communications B.V.; 2006.

11. Chauvineau V, Codine P, Herisson C, Pellas F, Pelissier J: What is the place of diphosphonates in the treatment of complex regional pain syndrome I? Ann Readapt Med Phys 2005, 48(3):150157.

12. Adami S, Fossaluzza V, Gatti D, Fracassi E, Braga V: Bisphosphonate therapy of reflex sympathetic dystrophy syndrome. Ann Rheum Dis 1997, 56(3):201-204.

13. Schott GD: Bisphosphonates for pain relief in reflex sympathetic dystrophy? Lancet 1997, 350(9085):1117.

14. Riet G, Kessels A: Validity checklist for clinical trials. Complementary Therapies in Medicine 1997(5):116-118.

15. Kirkwood B, Sterne J: Essential Medical Statistic, 2nd edn. Oxford, UK: Blackwell Publishing Limited; 2006.

16. Landis JR, Koch GG: An application of hierarchical kappa-type statistics in the assessment of majority agreement among multiple observers. Biometrics 1977, 33(2):363-374.

17. Manicourt DH, Brasseur JP, Boutsen Y, Depreseux G, Devogelaer JP: Role of alendronate in therapy for posttraumatic complex regional pain syndrome type I of the lower extremity. Arthritis Rheum 2004, 50(11):3690-3697.

18. Robinson JN, Sandom J, Chapman PT: Efficacy of pamidronate in complex regional pain syndrome type I. Pain Med 2004, 5(3):276-280.

19. Varenna M, Zucchi F, Ghiringhelli D, Binelli L, Bevilacqua M, Bettica P, Sinigaglia L: Intravenous clodronate in the treatment of reflex sympathetic dystrophy syndrome. A randomized, double blind, placebo controlled study. J Rheumatol 2000, 27(6):1477-1483.

20. Adami S, Fossaluzza V, Gatti D, Fracassi E, Braga V: Bisphosphonate therapy of reflex sympathetic dystrophy syndrome. Ann Rheum Dis 1997, 56(3):201-204. 
21. Manicourt DH, Brasseur JP, Boutsen Y, Depreseux G, Devogelaer JP: Role of alendronate in therapy for posttraumatic complex regional pain syndrome type I of the lower extremity. Arthritis Rheum 2004, 50(11):3690-3697.

22. Robinson JN, Sandom J, Chapman PT: Efficacy of pamidronate in complex regional pain syndrome type I. Pain Med 2004, 5(3):276-280.

23. Liens D, Lavoignat D, Meunier P, Delmas P: Bisphosphonates et Algodystrophie Réflexes. In: Actualités en réeducation fonctionelle et réadaptation. Edited by Simon L, Péllissier J, Hérisson C. Paris: Masson; 1995: 380-382.

24. Cohen $P$, Uebelhart D: Indications du Pamidronate disodique dans le traitement des algodystrophies post-traumatiques ou post-chirurgicales de l'extremité distale du membre supérieur. In: Progrès en MPR. Edited by Simon L, Pelissier J, Hérisson C. Paris: Masson; 1998: 510-514. 


\section{Appendix}

External Validity

Population

Intervention(s)

Outcomes

Duration of follow-up

Assessment of adverse effects

Internal Validity

Selection of a prognostically homogenous study population

Blinding of persons who assess inclusion criteria

Pre-stratification on prognostically relevant variables

Random allocation (description of procedure)

Registration of loss to follow-up

Blinding of patients

Blinding of persons(s) who implement interventions

Registration of co-interventions that bear on outcome for each group

Blinding of persons(s) who assess treatment effects

Check to what extent blinding was successful

Data description and analysis

Measures of central tendency and their confidence intervals

\section{Statistical methods}

The statistical methods

The way missing values were dealt with

An intention to treat analysis

The distributions of baseline characteristics

The way any unbalance in prognostic variables was adjusted for (if deemed necessary)

Compliance

Compliance (dose, timing) 


\section{CHAPTER 8}

General discussion 
The research presented in this thesis reflects the set of problems associated with CRPS. The topics addressed in this thesis work at the diagnostic-prognostic juncture and represent preparatory work for a long needed rigorous cohort study. In Chapter 2 we reported the results of a survey investigating patients' knowledge on the most salient features of CRPS and identifying patient characteristics associated with the level of knowledge. Our data indicate that many CRPS patients do not reach minimum knowledge about their disease as defined by clinical experts. Physicians should be aware that CRPS patients expect disease related information first and foremost from their caregivers. In particular, the patients concerned seek more information about therapy and general aspects of the illness. In Chapter 3 we described an expert agreed priority list of diagnostic and follow-up parameters in the diagnosis and management of CRPS 1. Although the current clinical guideline of diagnostic criteria for CRPS 1 is a landmark endeavour to define this complex condition it does not prioritize its most important clinical manifestations. We set out to obtain an expert agreed priority list of diagnostic and follow-up parameters in the diagnosis and management of CRPS 1 . This expert survey conveys an agreed set of relevant diagnostic parameters of CRPS 1 and proposes that in follow-up examinations treatment success should be based on restoration of those manifestations. In Chapter 4 we presented the rational and design of a prospective cohort study aiming at epidemiological, diagnostic, prognostic and socioeconomic investigations of a database and developing a prognostic risk assessment tool for patients with suspected CRPS 1 . We intend to set-up a prospectively acquired clinical database for two years. Ideally, potential risk factors may be identified at an early stage in order to initiate an early and adequate treatment in patients with increased risk for delayed recovery. In Chapter 5 we presented the results of the German translation and external validation of the Radboud Skills Questionnaire in patients suffering from CRPS 1. We demonstrated that the German version is a simple and reliable instrument to assess and quantify disabilities of patients suffering from CRPS 1 of the upper extremity for clinical and research purposes. In Chapter 6 we translated the Dutch Walking Stairs, Walking Ability and Rising and Sitting Questionnaire into German and assessed its construct validity with VAS measures of pain and activity in daily living. We showed that the domains pain and activity in daily living are properly represented in the German versions of the Walking Stairs, Walking Ability and Raising and Sitting Questionnaire. We would like to propagate their use in clinical practice and research alike. In Chapter 7 we reviewed the benefit of bisphosphonates in the treatment of CRPS 1 . Several studies found that bisphosphonates counteract locally increased bone resorption and associated pain in patients with CRPS 1. We performed a systematic review of all randomised controlled trials to assess the benefit of bisphosphonates in the treatment of CRPS 1 patients with bone loss. The very limited data reviewed showed that bisphosphonates have the potential to reduce pain associated with bone loss in patients with CRPS 1. However, at present there is not sufficient evidence to recommend their use in practice. 
Our investigations build on previous research activities presented by the TREND consortium from the Netherlands (www.trendconsortium.nl). Trauma RElated Neuronal Dysfunction is a collaborative effort of Dutch medical and technical universities and industrial companies, in which the research on epidemiology, assessment technology, pharmacotherapeutics, biomarkers and genetics of CRPS 1 is integrated. The consortium aims to develop concepts on disease mechanisms that occur in response to tissue injury and methods for its assessment and treatment. In our prospective cohort study we plan a stronger clinical focus aiming at identifying risk factors associated with delayed recovery at an early stage. This is important because the diagnosis of CRPS is often delayed, since the clinical appearance of this condition resembles normal post-traumatic states regarding pain, edema, and loss of function. In addition, our registry will help to enhance our collaboration with other international research groups such as TREND and CENTRIC (CRPS European NeTwork International Collaboration). This collaboration will allow us exchanging ideas and results across multi-disciplinary clinical and research teams, and establish common research tools for data collection.

In daily clinical practice patient care is rather based on individual experience than evidence based data. From a clinical standpoint future research should therefore focus primarily on epidemiological studies and clinical trials. Epidemiological studies should emphasize regarding incidence, prevalence and prognostic factors of CRPS 1. Clinical trials should investigate the efficacy of available treatment options with randomized controlled trials. The protocol of our cohort study aims at improving diagnosis and treatment of CRPS as well as identifying patients at risk for delayed recovery at an early stage. This is important because the clinical diagnosis of CRPS in trauma patients is often delayed, since the clinical appearance of this disease often resembles normal post-traumatic states regarding pain. According to the Swiss Accident Insurance (SUVA) a single CRPS case amounts to the considerable sum of 152'000 Swiss Francs within a ten year period whereas an average case comes to 5'200 Swiss Francs. We hope that our data also helps to have a impact on reducing CRPS related health care costs. Increased public awareness about the great socio-economic burden of CRPS has had considerable impact on regulatory bodies and national research programme coordinators to promote research in this under-studied clinical field recently. Latest research has raised the understanding about clinical manifestations that are typically associated with this multifaceted syndrome and studies on various therapeutic agents have been designed to measure their beneficial potential in the treatment of CRPS 1. However, today researchers still agree that further effort particularly regarding the diagnosis but also regarding the prognosis of CRPS 1 is mandatory to improve patient care.

Despite increasing research in this field the underlying mechanisms remain poorly understood and there is a lack of a uniform definition of this challenging disorder. Hence, it is rather individual experience than evidence based data that dominates daily clinical practice. Due to the heterogeneity of the available studies 
the results are difficult to compare and the findings are profound to interpret. Therefore the knowledge transfer from research into clinical practice is unsatisfactory.

With our research activities we expect to make a sustained contribution to the improvement of the management of CRPS 1. We hope that that patients afflicted with CRPS can benefit from our findings so that their degree of suffering and psychological strains caused by this complex and often debilitating condition can be reduced. 


\section{Summary}

The Complex Regional Pain Syndrome (CRPS) is a condition characterized by severe burning pain, pathological changes in the bone and the skin, excessive sweating, tissue swelling and extreme sensitivity to touch. Two types of CRPS are currently distinguished: type 1 , which occurs without a definable nerve lesion and type 2 , in which a definable nerve lesion is present. In both types, symptoms usually appear after an initiating noxious event such as trauma or surgery. The course varies from mild and self-limiting to a chronic disease with high impact on daily functioning and quality of life. This thesis focused on CRPS type 1 (CRPS 1).

Although CRPS 1 is commonly seen in clinical practice, the condition remains poorly understood. The broad spectrum of sometimes quite unspecific clinical manifestations and particularly the lack of pathognomonic signs or symptoms make the distinction between CRPS 1 and other conditions with similar manifestations challenging. Consequently, diagnosis is often delayed.

Despite increasing research in the field of CRPS 1 the exact mechanisms of the onset and course of the disease remain largely unknown. While basic science research has had some success lately, the clinical research agenda remains incompletely developed. For example, data on epidemiology, natural history and possible predisposing factors is limited. Moreover, registries aiming at capturing patients with CRPS 1 miss cases with a mild course of the disease because these patients only present with unspecific manifestations. Finally, there are only a few therapeutic concepts available showing some positive effect in the treatment of CRPS 1 and there is a dearth of systematic reviews in this area.

The research presented in the thesis should be seen as a contribution to this problem. This proposal comprises a series of projects which were performed at the Balgrist University Hospital in Zurich, Switzerland in close collaboration with the 
Horten Centre for Patient Oriented Research, of the University of Zurich (Switzerland).

In Chapter 2 we reported the results of a survey investigating patients' knowledge on the most salient features of CRPS. We also aimed at identifying patient characteristics associated with the level of knowledge. We first defined the minimum knowledge one could expect from a CRPS patient using a panel of experts and patients. From that set of items, we derived a questionnaire assessing the actual level of knowledge. We found that only six out of 101 patients reached that minimum level as stipulated from the panel. The number of correct answers correlated with educational level and to some extent with (para)medical background and was independent of duration of symptoms, patients' age or gender. Taking into account that knowledge is an important element for behavioural change our findings highlight the need for specific educational programs to raise the level of disease related knowledge in patients with CRPS.

In Chapter 3 we described an expert agreed priority list of diagnostic and follow-up parameters in the diagnosis and management of CRPS 1. Although the current clinical guideline of diagnostic criteria for CRPS 1 is a landmark endeavour to define this complex condition many clinicians find it hard to apply it. To investigate, whether a short version of the criteria list is feasible and valid, we set out to obtain an expert agreed priority list of diagnostic and follow-up parameters in the diagnosis and management of CRPS 1. Based on the experts' input and through a Delphi consensus procedure we succeeded deriving such a short version. The experts agreed that the most relevant diagnostic parameters of CRPS 1 are, pain with its subcategories hyperesthesia, hyperalgesia and allodynia, oedema and colour change and (lack of) mobility. Interestingly, the experts saw no role for imaging and lab tests for the diagnosis of CRPS 1 and also discouraged using them to evaluate treatment success.

In Chapter 4 we presented the rational and design of a prospective cohort study aiming at epidemiological, diagnostic, prognostic and socioeconomic investigations of a database and developing a prognostic risk assessment tool for patients with suspected CRPS 1 . We intend to set-up a prospectively acquired clinical database for two years. Ideally, potential risk factors may be identified at an early stage in order to initiate an early and adequate treatment in patients with increased risk for delayed recovery.

In Chapter 5 we presented the results of the German translation and external validation of the Radboud Skills Questionnaire in patients suffering from CRPS 1. We showed that the German version is a simple and reliable instrument to assess and quantify disabilities of patients suffering from CRPS 1 of the upper extremity for clinical and research purposes.

In Chapter 6 we translated the Dutch Walking Stairs, Walking Ability and Rising and Sitting Questionnaire into German and assessed its construct validity with VAS measures of pain and activity in daily living. We showed that the domains pain and activity in daily living are properly represented in the German versions of the Walk- 
ing Stairs, Walking Ability and Raising and Sitting Questionnaire. We would like to propagate the use of both instruments in clinical practice and research alike.

Results of clinical studies and anecdotic reports seemed to suggest that bisphosphonates could play a role in the treatment of patients with CRPS 1 , because they are said counteracting a locally increased bone resorption which reduces pain. To see, whether this assumption also holds when considering all available high quality research, we systematically reviewed all randomised controlled trials assessing the efficacy of bisphosphonates in the treatment of CRPS 1 in Chapter 7. The very limited data available for review showed that bisphosphonates have the potential to reduce pain associated with bone loss in patients with CRPS 1. However, at present there is not sufficient evidence to recommend their use in practice.

In conclusion, the rational of a prospective cohort study is the core part of this thesis. We plan a strong clinical focus aiming at identifying risk factors associated with delayed recovery at an early stage. This is important because the diagnosis of CRPS 1 is often delayed, since the clinical appearance of this condition resembles normal post-traumatic states. In addition, the set up of our study will offer unique opportunities for collaboration with other international research groups involved in CRPS 1 research such as TREND and CENTRIC (CRPS European NeTwork International Collaboration). The study is likely to generate considerable transfer value to the health care system: The development of new prognostic markers and targeted interventions avoiding also unnecessary treatments will have substantial potential for both cost savings and improvements in the quality of patient care. 



\section{Samenvatting}

Het Complex Regional Pain Syndrome (CRPS) is een chronische aandoening die wordt gekarakteriseerd door ernstige brandende pijn, pathologische veranderingen in het bot en de huid, overdadig zweten, zwellingen en een extreme gevoeligheid voor aanraken. Hierbij worden twee types onderscheiden: type 1, dat optreedt zonder aanwijsbare beschadiging van de zenuw en type 2, waarbij een aantoonbare beschadiging van de zenuw aanwezig is. In het algemeen treden de symptomen op na een schadelijk gebeurtenis zoals een ongeval of een operatie. Het beloop varieert van milde, begrensde aandoening tot een chronische ziekte met een grote invloed op het dagelijks leven en de kwaliteit van het leven. Dit proefschrift richt zich op CRPS type 1 (CRPS 1)

Alhoewel CRPS 1 in de klinische praktijk betrekkelijk vaak voorkomt, is van de aandoening nog weinig bekend. Door de grote verscheidenheid van de klinische manifestaties van CRPS1 en omdat er geen karakteristieke en unieke kenmerken voor CRPS 1 aanwezig zijn, is het moeilijk CRPS 1 van aandoeningen met vergelijkbare manifestaties te onderscheiden. Daarom wordt de diagnose van CRPS 1 vaak met vertraging gesteld].

Ondanks toenemend wetenschappelijk onderzoek op het gebied van CRPS 1 is het mechanisme van het ontstaan en het beloop van de ziekte nog grotendeels onbekend. Terwijl fundamenteel onderzoek recent enkele successen boekte, blijft succesvol klinisch onderzoek achter. Zo zijn gegevens over de epidemiologie, het natuurlijk beloop en mogelijke predisponerende factoren schaars. Bovendien missen de huidige registraties die het ziektebeloop van CPRS 1 vastleggen, patiënten met een mild beloop omdat bij deze patiënten vaak alleen aspecifiek manifestaties aanwezig zijn. Tenslotte zijn er slechts enkele therapeutische concepten beschikbaar die een beperkt effect laten zien bij de behandeling CRPS 1 en systematische literatuuroverzichten op dit gebied zijn schaars. 
Het onderzoek in dit proefschrift moet worden gezien als een bijdrage om voornoemde problemen op te lossen. Het bestaat uit een serie van onderzoeksprojeten die zijn uitgevoerd in het Balgrist Universiteitsziekenhuis in Zürich, Zwitserland in nauwe samenwerking met het Horten Centrum voor Patiëntgebonden Onderzoek van de Universiteit van Zürich.

In hoofdstuk 2 beschrijven we een prioriteitslijst voor de diagnose en management van CRPS 1, zoals deze door experts is vastgesteld. Alhoewel de huidige richtlijnen voor diagnostische kriteria van CRPS 1 als een mijlpaal kunnen worden gezien om deze complexe ziekte te definiëren, vinden veel clinici het moeilijk deze criteria toe te passen.

Om te onderzoeken of een verkorte lijst van kriteria uitvoerbaar en valide is, hebben we een door experts vastgestelde prioriteitslijst van diagnostische en nazorg parameters in de behandeling van CRPS 1 samengesteld. Gebaseerd op de input van experts en met behulp van een Delphi procedure zijn we erin geslaagd een dergelijk verkorte versie tot stand te brengen. Deze experts kwamen gezamenlijk tot de conclusie dat de meest relevante diagnostische parameters van CRPS 1 zijn: pijn, met name overgevoeliheid voor pijn en aanraken, oedeem, kleurverandering en beperking van de mobiliteit.

In hoofdstuk 3 beschrijven wij de resultaten van een onderzoek naar de kennis van patiënten over de meest in het oog springende kenmerken van CRPS 1. Tevens is gekeken naar de samenhang tussen patiëntenkenmerken en de mate van deze kennis. Met behulp van een panel bestaande uit patiënten en experts hebben we eerst een minimum kennisniveau vastgesteld dat bij CRPS 1 patiënten kan worden verwacht. Van deze items hebben we een enquête afgeleid waarmee het kennisniveau kon worden vastgesteld. We vonden dat slechts zes van de 101 patienten hoger scoorde dan een vooraf door het panel vastgeteld minimum kennisniveau. Het aantal correcte antwoorden hing samen met het opleidingsniveau, in beperkte mate met de (para)medische achtgrond en was onafhankelijk van de duur van de symptomen, de leeftijd en het geslacht.Omdat kennis een belangrijk element van gedragsaanpassingen zijn, benadrukken deze resultaten het belang van specifieke voorlichtingsprogramma's om het kennisnivea over CRPS 1 bij deze patiënten te verhogen

In hoofdstuk 4 beschrijven we de rationale en het ontwerp van een prospectieve cohortstudie met als doel de epidemiologische, diagnostische, prognostische en socio-economische aspecten van de CRPS 1 te onderzoeken en om een prognostisch risicoprofiel voor deze patiënten te ontwikkelen. De bedoeling is om een klinische database aan te leggen van patiënten die twee jaar lang worden gevolgd. Op deze wijze kunnen vroege risicofactoren worden geïdentificeerd om een tijdige en adekwate behandeling van, in het bijzonder, patiënten met een risico op een vertraagd herstel, mogelijk te maken.

In hoofdstuk 5 presenteren we de resultaten van een Duitse vertaling van de Radboud Skills Questionnaire in patiënten met CRPS 1 en van de externe validatie van deze vertaling. We tonen aan dat de Duitse versie een eenvoudig en betrouw- 
baar instrument is om de lichamelijke ongeschiktheid van de bovenste extremiteit van CRPS 1 patiënten vast te stellen en te kwantificeren. Dit meetinstrument kan zowel klinisch als voor wetenschappelijk onderzoek worden gebruikt.

In hoofdstuk 6 beschrijven we de Duitse vertaling van de Dutch Walking Stairs, Walking Ability en Rising and Sitting Questionnaire en hebben we met behulp van Visuele Analoge Schaal (VAS) metingen van pijn en dagelijkse activiteiten, de construct validiteit bepaald. We tonen aan dat de domeinen pijn en dagelijkse activiteit voldoende vertegenwoordigd zijn in deze Duitse vertaling van de Walking Stairs, Walking Ability en Rising and Sitting Questionnaire en we adviseren het gebruik van deze lijst in de kliniek en voor wetenschappelijk onderzoek.

De resultaten van klinische studies en case reports suggereren dat bisfosfonaten een rol zouden kunnen spelen bij de behandeling van patiënten met CRPS 1 , omdat deze lokaal verhoogde botresorptie en de daarmee samenhangende pijn teniet doen. Om na te gaan of deze veronderstelling ook overeind blijft indien de informatie van alle beschikbaar onderzoek met voldoende kwaliteit in beschouwing wordt genoemd, hebben we in hoofdstuk 7 een systematische literatuurstudie beschreven van alle gerandomiseerde studies die het effect van bisfosfonaten onderzochten. De zeer beperkte hoeveelheid gegevens die voor dit overzicht aanwezig was, toonden aan dat bisfosfonaten potentieel de pijn die met botverlies bij patiënten met CRPS 1 samenhangt, kan verminderen. Op dit moment is echter de bewijskracht van deze studies te gering om bisfosfonaten in de praktijk aan te bevelen.

Afrondend, de rationale van een prospectieve cohort studie is de kern van dit proefschrift. We richtten ons op het identificeren van risicofactoren die samenhangen met een vertraagd herstel in het vroege stadium van deze ziekte. Dit is belangrijk omdat de diagnose van CRPS 1 vaak vertraagd is, omdat de klinische manifestatie van deze aandoening in hoge mate op algemene post-traumatische kenmerken lijkt. In aanvulling hierop, zal deze cohort studie een unieke gelegenheid bieden om met andere onderzoeksgroepen zoals TREND (Trauma RElated Neuronal Dysfunction) en CENTRIC (CRPS EuropeanNetwork International Collaboration) samen te werken. Het is aan te nemen dat deze studie veel informatie zal verschaffen ten behoeve van de gezondheidszorg: Het ontwikkelen van nieuwe prognostische markers en gerichte interventies waardoor onnodige behandelingen worden vermeden. Tevens zal het mogelijk zijn om zowel kostenbesparingen als verbetering van de levenskwaliteit van deze patiënten te realiseren. 



\section{Dankwoord}

First of all I would like to thank Lucas M Bachmann, a friend and extraordinary mentor, who supervised this thesis and contributed to all of the chapters.

I am grateful to Rudolf Kissling, my boss at Balgrist University Hospital for his commitment, generosity and support that allowed me to focus on the completion of this thesis.

I am grateful to Johann Steurer, Director of the Horten Centre of the University of Zurich, for his helpful advices and for permitting me to be a member of his research team.

I am also very grateful that Marten van Kleef agreed to act as the promoter for this thesis. It is indeed a great honour to me. I would also like to thank his secretary Hermina Gielen for her support.

Margareta Nordin has played a great role in my personal development and in research. She organized my fellowship at the New York University (USA) that allowed me to participate in her projects and in her research team.

Research is usually a collaborative effort. I would therefore like to thank all the remaining co-authors for their excellent work: Alfons Kessels (Chapter 4, 5, 6), Roberto Perez (Chapter 4, 5, 6), Johan Marinus (Chapter 4, 5, 6), Ulrich Weber (Chapter 3 and 4), Carolin Heitz (Chapter 5 and 6), Adrian Gymesi (Chapter 2), Steffi Lienhardt (Chapter 3), Gerben ter Riet (Chapter 5), Anne Leibfried (Chapter 6), Annina Schmid (Chapter 7) and Ulrike Held (Chapter 7). 



\section{Curriculum vitae}

Florian Brunner was born in Zurich, Switzerland on August 4th, 1969. After obtaining his high school diploma from Realgymnasium Rämibühl in Zurich in 1988, he read medicine at the University of Zurich, graduating in 1995. In 1996 he completed his MD thesis about knee arthroscopy in professional football players. His professional career included clinical training in general surgery, orthopedic surgery, internal medicine, neurorehabilitation, rheumatology and physical medicine. Between July 2003 and July 2004 he worked as a research fellow at the Occupational and Industrial Orthopaedic Center (OIOC), Hospital for Joint Diseases Orthopaedic Institute, Mt.Sinai NYU Health Program, Program of Ergonomics and Biomechanics New York University, in New York. In 2004 he passed the Swiss and the European board certification in Physical Medicine and Rehabilitation. In August 2004 he began to work as a senior physician at the Department of Physical Medicine and Rheumatology, Balgrist University Hospital in Zurich, Switzerland. Since 2007 he is also working as a research fellow at the Horten Centre, University of Zurich (part time). The work undertaken for this thesis was carried out in the year from 2005-2009. 



\section{List of publications}

(last update september 24th, 2009)

\section{Original studies (peer reviewed)}

Brunner F, Hotz Th, Käch K: Distale Bicepssehnenrupturen - Erfahrungen mit der weichteilschonenden Reinsertion mittels Knochenanker. Swiss Surg 1999;5(4):186-90.

Kessler J, de Bruin E, Brunner F, Vienne P, Kissling R: Effect of manual lymph drainage after hindfoot operations. Physiother Res Int 2003;8(2):101-10.

Kessler J, Brunner F, Kunzer S, Crippa M, Kissling R: Effects of Maitland's manual mobilization on the thoracic spine. Rehabilitation, 2005;44(6):361-6.

Brunner F, Kunz A, Weber U, Kissling R: Ankylosing spondylitis and heart abnormalities: do cardiac conduction disorders, valve regurgitation and diastolic dysfunction occur more often in male patients with diagnosed ankylosing spondylitis for over 15 years than in the normal population? Clin Rheumatol. 2006 Feb;25(1):24-9. Epub 2005 Oct 25.

Meningardi B, Schmid MR, Boos N, Pfirrmann CW, Brunner F, Elfering A, Hodler J: Fat content of lumbar paraspinal muscles in patients with chronic low back pain and in asymptomatic volunteers: Quantification with MR Spectroscopy. Radiology 2006, Sep:240(3):786-92.

Brunner F, Lienhard SB, Kissling RO, Bachmann LM, Weber U: Diagnostic criteriea and follow-up parameters in complex regional pain syndrome type 1 - a Delphi survey. Eur J Pain 2008 Jan;12(1):48-52. Epub 2007 Apr 2.

Brunner F, Schmid A, Sheikhzadeh A, Nordin M, Jangwhon Y, Frankel V: Effects of aging on type 2 muscle fibers - A systematic review of the literature. J Aging Phys Act 2007, Jul;15(3):336-48. 
Schmid A, Brunner F, Wright T, Bachmann LM: Paradigm Shift in Manual Therapy?

Evidence for a central nervous system component in the response to Passive Cervical Joint Mobilization - A Systematic Review. Manual Therapy 2008, Oct;13(5):387-96. Epub 2008 Mar 3

Luginbühl R, Brunner F, Schneeberger A: No effect of forearm band and extensor strengthening exercises for the treatment of tennis elbow: a prospective randomised study. Chir Organi Mov 2008, Jan;91(1):35-40. Epub 2008 Feb 10

Brunner F, Schmid A, Kissling R, Held U, Bachmann LM: The Role of Bisphosphonates in Therapy for Complex Regional Pain Syndrome 1 - Qualitative and Quantitative Meta-Analysis. Eur J Pain 2009, Jan;13(1):17-21. Epub 2008 Apr 28.

Schmid A, Brunner F, Lomajoki H, Held U, Bachman LM, Kuenzer S, Coppieters M. Reliability of clinical tests to evaluate nerve function and mechanosensitivity of the upper limb peripheral nervous system. BMC Musculoskeletal Disorders. 2009, Jan 21;10:11.

Heitz CAM, Hilfiker R, Bachmann LM, Joronen H, Lorenz T, Uebelhart D, Klipstein A, Brunner $F$. Comparison of risk factors predicting return to work between patients with subacute and chronic non-specific low back pain: Systematic review. Eur Spine J, June 30th, 2009 (epub ahead of print).

Schmid A, Dyer L, Böni T, Held U, Brunner F. Paraspinal muscle activity during symmetrical and asymmetrical weight training in idiopathic scoliosis. Accepted. Journal of Sport Rehabilitation, September 2009.

\section{Currently under review (peer reviewed)}

Brunner F, Heitz CAM, Kissling R, Kessels AGH, Perez RSGM, Marinus J, ter Riet G, Bachmann LM. German translation and external validation of the Radboud Skills Questionnaire in patients suffering from CRPS 1. Under review. BMC Musculoskeletal, July 2009.

Brunner F, Gymesi A, Kissling R, Bachmann LM. Disease-related knowledge of patients with Complex Regional Pain Syndrome. Under review. Journal of Rehabilitation Medicine, April 2009.

Heitz C, Bachmann LMB, Leibfried A, Kissling R, Kessels AGH, Perez RSGM, Marinus J, Brunner F: Translating the Dutch Walking Stairs, Walking Ability and Rising and Sitting Questionnaire into German and assess its construct validity with VAS measures of pain and activity in daily living. Under review. BMC Musculoskeletal, July 2009. 


\section{Case reports}

Kessler J, Brunner F, Enzler M, Kissling R: Über den Vorteil und Nutzen einer stationären, interdisziplinären Rehabilitation. Manuelle Medizin 2002, 2:94-96.

Huggler M, Kissling R, Brunner F: Bone metastases mimicking Complex Regional Pain Syndrome 1: a case report. J Med Case Reports. 2008 Nov 17;2(1):345.

\section{Reviews, non peer reviewed}

Brunner F, Dumont C: Neue Trends in der Handchirurgie. Medizin Spiegel 5/2000;17-21.

\section{Book chapters}

Brunner F, Weiser S, Nordin M: Physical Therapy, Reconditioning, Learning How to Move Again. In: The Failed Spine, p. 157-163. Ed: M. Spalsky. R. Gunzburg. Lippincott Williams \& Willkins, Philadelphia, 2005.

Brunner F, Wecter S, Campello M, Nordin M: Rehabilitation Guidlines. In: The Medical Disability Advisor: Workplace Guidlines for Disability Duration. Ed: P. Reed. Reed Group. 5th Edition, 2005.

Brunner F, Schecter Weiner S, Kissling R: Postoperative rehabilitation. In: Spinal Disorders - Fundamentals of Diagnosis and Treatment. Springer Verlag, Heidelberg. Ed: Boos N., Aebi M. 2008.

Brunner F, Schmid A, Schecter Weiner S, Weiser S, Nordin M: Non specific low back pain. In: Spinal Disorders - Fundamentals of Diagnosis and Treatment. Springer Verlag, Heidelberg. Ed: Boos N, Aebi M. 2008.

\section{Dissertations}

Kunz A (2004): Ankylosierende Spondylitis und Herzabnormalitäten: Treten Rhythmusstörungen, Klappendysfunktionen und diastolische Dysfunktionen häufiger auf unter männlichen Patienten mit nachgewiesenem Morbus Bechterew?

Gymesi A (2009): Disease related knowledge in patients suffering from Complex Regional Pain Syndrome. 


\section{Other publications}

Brunner F, Bachmann LM., Weber U., Kessels AGH, Perez RSGM., Marinus J., Kissling R.: Complex regional pain syndrome 1 - the Swiss cohort study. BMC Musculoskeletal Disorders. 2008, 9:92.

Brunner F: Zur Studie von Kirkley A et al.: A randomized trial of arthroscopic surgery for osteoarthritis of the knee. Praxis. 2008; 97: 1347-1347. 